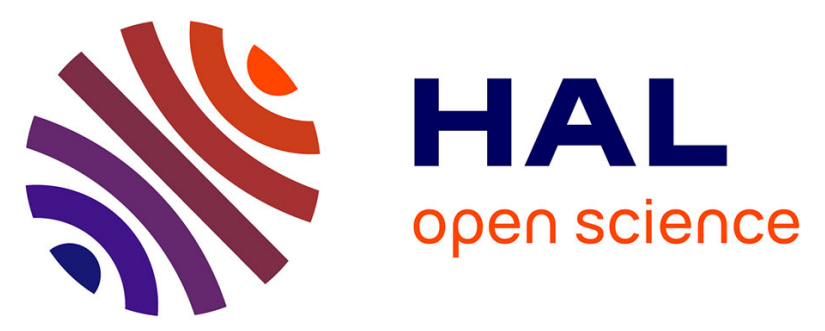

\title{
Large-scale margin collapses along a partly drowned, isolated carbonate platform (Lansdowne Bank, SW Pacific Ocean)
}

Samuel Etienne, Pascal Le Roy, Elsa Tournadour, Walter R Roest, Stephan Jorry, Julien Collot, Martin Patriat, Maria A Largeau, Jean Roger, Camille Clerc, et al.

\section{To cite this version:}

Samuel Etienne, Pascal Le Roy, Elsa Tournadour, Walter R Roest, Stephan Jorry, et al.. Large-scale margin collapses along a partly drowned, isolated carbonate platform (Lansdowne Bank, SW Pacific Ocean). Marine Geology, 2021, 436, pp.106477. 10.1016/j.margeo.2021.106477 . insu-03211738

\section{HAL Id: insu-03211738 \\ https://hal-insu.archives-ouvertes.fr/insu-03211738}

Submitted on 29 Apr 2021

HAL is a multi-disciplinary open access archive for the deposit and dissemination of scientific research documents, whether they are published or not. The documents may come from teaching and research institutions in France or abroad, or from public or private research centers.
L'archive ouverte pluridisciplinaire HAL, est destinée au dépôt et à la diffusion de documents scientifiques de niveau recherche, publiés ou non, émanant des établissements d'enseignement et de recherche français ou étrangers, des laboratoires publics ou privés. 


\section{Journal Pre-proof}

Large-scale margin collapses along a partly drowned, isolated carbonate platform (Lansdowne Bank, SW Pacific Ocean)

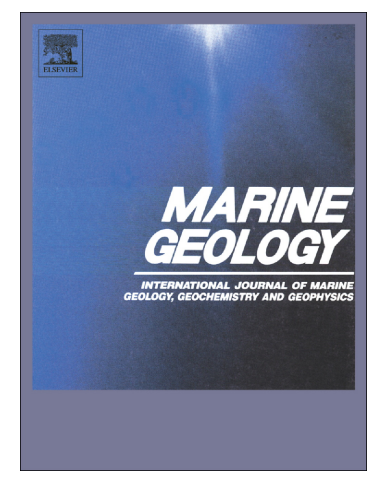

Samuel Etienne, Pascal Le Roy, Elsa Tournadour, Walter R. Roest, Stephan Jorry, Julien Collot, Martin Patriat, Maria A. Largeau, Jean Roger, Camille Clerc, Belinda Dechnick, Kelsey L. Sanborn, Fanny Lepareur, Jeremy Horowitz, Jody M. Webster, Arnaud Gaillot

PII: S0025-3227(21)00059-1

DOI: https://doi.org/10.1016/j.margeo.2021.106477

Reference: MARGO 106477

To appear in: Marine Geology

Received date: 20 August 2020

Revised date: 1 April 2021

Accepted date:

3 April 2021

Please cite this article as: S. Etienne, P.L. Roy, E. Tournadour, et al., Large-scale margin collapses along a partly drowned, isolated carbonate platform (Lansdowne Bank, SW Pacific Ocean), Marine Geology (2018), https://doi.org/10.1016/j.margeo.2021.106477

This is a PDF file of an article that has undergone enhancements after acceptance, such as the addition of a cover page and metadata, and formatting for readability, but it is not yet the definitive version of record. This version will undergo additional copyediting, typesetting and review before it is published in its final form, but we are providing this version to give early visibility of the article. Please note that, during the production process, errors may be discovered which could affect the content, and all legal disclaimers that apply to the journal pertain.

(C) 2018 C 2021 Published by Elsevier B.V. 


\title{
Large-scale margin collapses along a partly drowned, isolated carbonate platform (Lansdowne Bank, SW Pacific Ocean)
}

\author{
Samuel ETIENNE ${ }^{1,2}$, Pascal LE ROY ${ }^{3}$, Elsa TOURNADOUR ${ }^{2,4}$, Walter R. ROEST ${ }^{4}$, Stephan JORRY ${ }^{4}$, Julien \\ COLLOT $^{2}$, Martin PATRIAT ${ }^{4}$, Maria A. LARGEAU ${ }^{2}$, Jean ROGER ${ }^{5 *}$, Camille CLERC ${ }^{6}$, Belinda DECHNICK ${ }^{7}$, \\ Kelsey L. SANBORN ${ }^{7}$, Fanny LEPAREUR ${ }^{8}$, Jeremy HOROWITZ ${ }^{9}$, Jody M. WEBSTER ${ }^{7}$, Arnaud GAILLOT ${ }^{4}$. \\ ${ }^{\text {I} A D E C A L ~ T e c h n o p o l e, ~ Z o N e ́ C o ~ R e s e a r c h ~ P r o g r a m, ~} 98846$ Nouméa, New Caledonia. \\ ${ }^{2}$ Geological Survey of New Caledonia, DIMENC, BP M2, 98845 Nouméa, New Caledonia. \\ ${ }^{3}$ Laboratoire Géosciences Océan UMR 6538, Université de Bretagne Occidentale, 29280 Plouz ne, . vance. \\ ${ }^{4}$ IFREMER, Unité Géosciences Marines, 29280 Plouzané, France \\ ${ }^{5}$ Institut de Recherche pour le Développement (IRD), 98848 Nouméa, New Caledonia, * now + sNS Science, Wellington, New Zealand \\ ${ }^{6}$ ISEA, Université de la Nouvelle-Calédonie, 98851 Nouméa, New Caledonia \\ ${ }^{7}$ Geocoastal Research Group, School of Geosciences, University of Sydney, NSW 200, 4ustralia \\ ${ }^{8}$ Museum National d'Histoire Naturelle, 75005 Paris, France

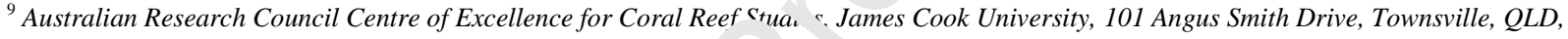 \\ 4811, Australia
}

Key words: Isolated carbonate platforn. margin collapse, slope failure, MTCs.

\begin{abstract}
The Lansdowne B $\mathrm{nk}$ is a partly drowned, isolated carbonate platform of around $4000 \mathrm{~km}^{2}$ located $300 \mathrm{~km}$ west of Nev Caledonia, in the SW Pacific Ocean, in water depths of 20 to $100 \mathrm{~m}$. New multibeam bathymetric data, high resolution seismic reflection profiles and sediment gravity cores have been acquired on the bank top and adjacent slopes. This dataset reveals an almost continuous $4 \mathrm{~km}$ wide outer reef rim located in $c a .50 \mathrm{~m}$ water depth, surrounding a gently deepening inner platform, reaching up to $100 \mathrm{~m}$ water depth. The bank is bordered by very steep slopes showing numerous erosional morphologies such as canyons, channels and gullies. Along with these bypass features, spectacular bank
\end{abstract}


margin collapses and slope failures are evidenced by up to $20 \mathrm{~km}$-wide bank edge and intraslope failure scars, respectively, resulting in a typical "scalloped" geometry of the bank margin. These failure scars can lead to a complete collapse of the outer reef rim and impact subsequent reef development. Bank margin collapses are evidenced by hectometer to kilometer-scale blocks and debris shed on the slope, likely emplaced by rock fall/avalanching processes originating from the brittle failure of early cemented bank edge and upper slope sediments. In turn, failures triggered on the $u_{1 .}$ semented mud-prone middle to lower slopes likely generate more cohesive, submarine debris flows th ?t $r$ suld be at the origin of erosive morphologies within the debris fields. Estimated individual i. ilure volumes can reach up to $3 \mathrm{~km}^{3}$. Quaternary sea-level lowstands, that would have led to pla for $\eta$ exposure, fracturing and karstification, and the development of an erosional sea cliff, as $w \epsilon^{11}$ as subsequent rising sea-level are believed to play a significant role in mass wasting event emplace, ant, yet "bottom up" submarine processes such as the upslope propagation of bypass morphol gi is hy retrogressive headward erosion cannot be ruled out. In terms of geomorphic and stratigran lic onstraints, the documented bank margin collapses affect a terrace located in $70 \mathrm{~m}$ water depth ar ' $\mathrm{In} \mathrm{I}$ the bank, which, depending on its age and origin, could provide a minimum age for collapse v vents. Finally, considering the shallow water depth of failure headscarps, the volumes of material involved in the slides as well as their vicinity to the nearby main island of New Caledonia, numerical simulations of the tsunamigenic potential of submarine slides have been performed. They showed that these slides would have been able to produce a meter-scale wave that would reach the northern coast of the island in less than an hour. 


\section{INTRODUCTION}

Modern carbonate platforms have been extensively documented around the world (Emery et al., 1954; Reijmer et al., 2009; Gischler, 2006, 2011; Harris et al., 2011; Kench et al., 2015; Jorry et al., 2016; Hamylton et al., 2017) and are natural laboratories to study carbonate sedimentary facies and associated depositional processes. Carbonate platforms also form sensitive proxies to reconstruct Quaternary sealevel fluctuations (Woodroffe and Webster; 2014, Puga-Bernabéu et a', 2016; Rovere et al., 2018) or vertical tectonic movements (Taylor et al., 1987; Cabioch et al., 1998, Pe loja et al., 2014; Munch et al., 2014; Leclerc et al., 2014). Our knowledge of modern carbu ate slopes has improved due to recent acquisition of high resolution multibeam bathymetry and $\mathrm{s}$,iss. ${ }^{\mathrm{c}}$ data, notably around the Bahamas and in the Indian Ocean, revealing their morphologies $\neg$ nd cuntrolling sedimentary processes (Mulder et al., 2012a, 2012b; Betzler et al., 2016a; Tournadou ^t al., 2017; Counts et al., 2018; Wunsch et al., 2018; Jorry et al., 2020).

Although diverse processt s c.ntribute to remobilising sediments in such environments, from density cascading (Wilson ana Ro'erts, 1995; Counts et al., 2019), episodic downslope gravity flows (Eberli, 1991; Andresen el 1., 2003; Droxler and Schlager, 1985; Glaser and Droxler, 1993; Jorry et al., 2008, 2010; Mullins et al., 1984; Schlager et al., 1994; Webster et al., 2012) to more sustained contour currents (Betzler et al., 2014, 2016b; Lüdmann et al., 2013, 2018), it has been widely documented both in ancient and modern settings that carbonate slopes are characterized by large-scale gravitational collapses (e.g. Mullins and Hine, 1989; Boselinni et al., 1993; Borgomano, 2000; Janson et al., 2010; Correa et al., 2011; Jo et al., 2015; Tournadour et al., 2015; Principaud et al. 2015; Puga-Bernabéu et al., 2017; Counts et al., 2018; Le Goff et al., 2020). These mass wasting processes play a key role in shaping the platform 
edge and slope, in the stratigraphic evolution of the margin as well as in the export of margin and slopederived sediments into deep-water environments. Associated landslide scars can form large-scale embayments of the platform edge, resulting in what was classically described as "scalloped margins" (Mullins and Hine, 1989). These features are typically associated with accumulations of fallen blocks and debris at the base-of-slope (e.g. "carbonate megabreccias" of Hine et al., 1992). Consequently, many of the depositional models depicting carbonate slope architectures inci red mass wasting as a central process, from the classical "debris sheet" model of Cook et al. (1972, an $r$ the "carbonate apron" models of Cook and Mullins (1983), to the more complex "debris-dom. 'ated" models compiled in Playton et al. (2010).

In this study, we present new data on a patly urowned, isolated carbonate platform of the SW Pacific Ocean, the Lansdowne Bank, which is . pified by large-scale (tens of kilometers long) failure scars affecting the slope and the platfor a 'ur rgin, thus conforming to a "scalloped margin". Along with the overall characteristics of the $b c^{n k}$ : pp, we document margin collapse and slope failure morphologies and discuss their relative chro olr gy, potential emplacement mechanisms and controlling factors. In addition, we address the ts namigenic potential of an individual submarine but representative landslide through numerical simulations, particularly with regards to potential hazards along the coast of the nearby main island of New Caledonia. This case study highlights the role of catastrophic sediment collapses on platform edge and slope morphologies, as well as in the export of platform edge sediments towards deepwater environments. It also highlights the impact of margin collapses on the external platform morphologies, which can lead to a complete collapse of outer reef rims and can influence post-failure reef development, typically distributed along failure scars that reshape the geometry of the bank edge. 


\section{REGIONAL SETTINGS}

The Lansdowne Bank is an extensive, $150 \mathrm{~km}$-long and 10-50 km wide bathymetric high of around $4000 \mathrm{~km}^{2}$ located in the SW Pacific Ocean (Fig. 1). It is remote from any major terrigeneous sediment source and lies at water depths ranging from 20 to $100 \mathrm{~m}$. It is located $300 \mathrm{~km}$ west of New Caledonia, at the northernmost extremity of the Lord Howe Rise and the Fairway Ridge. The latter two structural features are part of the SW Pacific ridge and basin sy ${ }^{+} 2 \mathrm{~m}$, commonly referred to as “Zealandia" (Luyendyk, 1995; Mortimer et al., 2017), a mostly su merged fragment of thinned continental crust isolated during the Cretaceous breakup of the c stern Gondwana margin and opening of the Tasman Sea (Gaina et al., 1998). The Fairway Ridge is a ' 10 km-long, NW-SE oriented, southward deepening basement structure inherited from this 'retaueous rifting (Vially et al., 2003; Lafoy et al., 2005; Collot et al., 2009). In relation to Late Eo `ne obduction tectonics in New Caledonia (Collot et al., 2008), the Fairway Ridge is uplifted ir it, nrthernmost part at the Lansdowne Bank, at the junction between three deep-water basins: t 1e . Tirway Basin in the South, the New Caledonia Basin in the East and the Northern Middleton Ba in in the West, also called Lord Howe Basin (Launay et al., 1977) or North Lord Howe Basin (A rende et al., 1999) (Fig. 1).

Although no multibeam bathymetry data coverage existed prior to this study, the Lansdowne Bank has been formerly described as a "submerged atoll" with a barrier reef at around 30-40 m water depth, surrounding an internal lagoon up to $90 \mathrm{~m}$ deep (Mignot, 1984; Richer de Forges et al., 1986; 1988; Missègue et al., 1998). Sedimentary samples are sparse but available samples within the inner part of the bank revealed that bioclastic sands and Halimeda meadows prevail (Richet de Forges \& Pianet, 1984). Most of the bank is submerged and overall planar, yet a deepening towards the south-east was 
reported (Missègue et al., 1998). The fact that the northern part of the bank is shallower than the southern part is evidenced by a $20 \mathrm{~km}$-long stripe of living reef, called Nereus Reef (Fig. 1). Dominant winds (southeastern trade winds) are roughly parallel to the overall orientation of the Fairway Ridge and the Lansdowne Bank. The southern and western margins of the latter can be thus considered as windward margins, and the eastern and northern margins as leeward margins. Unlike the platform top, the slopes of the Lansdowne Bank have been partly imaged with multibeam bathyme ${ }^{\text {ric }}$ data from past oceanographic cruises (see data and methods). These data reveal prominent erosiona ser loor features such as canyons, channels and gullies, organized radially from the bank (Fig. 1). These bypass features seem to originate both from the slope and from the platform margin. Indeed, sn `re western slope of the Lansdowne Bank, towards the Northern Middleton Basin, tributary ce'"yolı, up to $250 \mathrm{~m}$ deep and typically 2-3 km wide, merge downslope into low sinuosity channels, $w_{2}$ - reas upslope they seem to reach the platform edge. On the northern slope, canyons are narrow $\mathrm{C}_{\mathrm{r}} \mathrm{H}^{\mathrm{N}}$ associated with failure scars on the slope. On the eastern slope, tributary canyons are also $\mathrm{r}$ es $n t$ among which the deeply incised (up to $800 \mathrm{~m}$ ), 3-4 km wide, sinuous Lansdowne Canyon is '. 'nost prominent (Williams et al., 2016; Mortimer et al., 2019; Fig. 1). The updip knickpoint of th. latter is located on the slope in around $1500 \mathrm{~m}$ water depth. On the southern slope, towards the Fairway Basin, available swath coverage revealed fewer and less prominent erosional features, possibly due to lower gradients of the slope and/or higher sedimentation rates, but a NW-SE oriented channel-lobe system is known further south in the basin (Rouillard et al., 2017; Pattier et al., 2019). We decided to map the updip continuation of slope features towards the Lansdowne Bank upper slope and bank edge (Fig. 2), notably to address the potential connection between slope features and 
platform top morphologies (e.g. inlets), and, in a general manner, to track any morphological expressions of platform-to-basin sediment transfer.

\section{DATA AND METHODS}

The SEDLAB cruise (Etienne et al., 2018) was conducted from 7th April to 5th May 2018 onboard the French R/V Alis and acquired geophysical and geological data in the Lansdowne Bank area (Fig. 2). Multibeam bathymetry was acquired with a Kongsberg EM106?' nultibeam echosounder capable of mapping in water depths up to $1000 \mathrm{~m}$. Processing of the multibea $n \mathrm{~h}$,thymetric data was performed with GLOBE software (Ifremer). High-resolution seismic refle tion profiles were acquired on the bank top using a 250 to $160 \mathrm{~J}$ Sparker source, a single char aeı SIG streamer and a numerical DELPH acquisition system. Shooting rate ranged from $3^{\prime} 0$ to $500 \mathrm{~ms}$ at 5 knots. Seismic processing was performed with DELPH software (gain control, :Itering 240-1000 Hz and swell correction). Superficial sediment samples were collected on the $\mathrm{a}^{\mathrm{r}}{ }_{\wedge}{ }^{\dagger}{ }^{\mathrm{op}} \mathrm{p}$ with a gravity Küllenberg corer with a three meter long barrel. Sediment cores were split in ha. ${ }^{c}$ longitudinally and documented with high resolution photographs. In total, the cruise acquired an 'In $12100 \mathrm{~km}^{2}$ of multibeam data, seven seismic profiles totaling 328 kilometers and eight gravı, cores (up to $1.8 \mathrm{~m}$-long), representing $9.6 \mathrm{~m}$ of unconsolidated sediments in total. These new data supplement those of earlier cruises, notably DSDP site 587 (Kennett et al., 1986; Fig. 1); ZoNéCo-04 cruise (Le Suavé, 1996; Missègue et al., 1998) as well as ECOSAT and ECOSAT II cruises (Seton et al., 2016; Williams et al., 2016; respectively). A sedimentary facies analysis of platform top environments has been performed, and sediments from eight cores have been described in terms of texture, lithology and nature of main components using a binocular microscope. Map production and geomorphological analysis of seafloor features was realized with ArcGIS (Esri), notably to estimate 
sediment volumes involved in margin collapses (see section 4.7). Tsunami modeling has been performed with the GEOWAVE software (Watts et al., 2003) which has been widely used and validated throughout different real tsunami case studies (e.g. Watts and Tappin, 2012). GEOWAVE takes into account that most tsunamis triggered by landslides show a dispersive and nonlinear behavior. A first module called TOPICS (Tsunami Open and Progressive Initial Conditions System) allows to generate the initial deformation surface. The latter is subsequently introduced within a st`ond module called FUNWAVE which computes the tsunami long wave propagation (Chen et al., 20し $\cdot$ k.ennedy et al., 2000) under the fully nonlinear Boussinesq equations (Wei et al., 1995; Wei .nd Kirby, 1995). The digital elevation model used for tsunami simulation comes from a samplin, $\mathrm{O}_{1}$ a regional $500 \mathrm{~m}$ resolution bathymetric grid (DTSI, 2009) combined with high resolution d a huın SEDLAB. The final grid has 750 x 750 cells at $500 \mathrm{~m}$ resolution and includes the Lansdowne ' ' ank and the northern part of New Caledonia mainland.

\section{RESULTS}

\subsection{Bank top morphologies}

Our multibeam bathvn $n^{-t r i}$, data document for the first time the detailed physiography of the Lansdowne Bank, which c uld be described as a partly drowned, isolated platform (sensu Tucker and Wright, 1990) or as a detached rimmed shelf (sensu Handford and Loucks, 1993; Wright and Burchette, 1996). The platform top extends over an area of $3860 \mathrm{~km}^{2}$, as revealed by our complete bank edge survey (Fig. 3). It has an atoll-like morphology (“empty bucket” geometry sensu Schlager, 1981, 1989), with an almost continuous 3-4 km wide outer reef rim, typically lying between 40 to $60 \mathrm{~m}$ water depths, surrounding an inner platform that gently deepens towards the center of the bank, typically at water depths between 50 to $70 \mathrm{~m}$, but locally up to $100 \mathrm{~m}$ deep (Figs. $2 \& 3$ ). The platform top is not entirely 
symmetric, and a southeastern deepening of the bank is observed. This deepening has been attributed by Missègue et al. (1998) to a NW-SE normal fault delimiting the northern margin (Fig. 3). Such structurally inherited topography might explain the shallower water depths in the northern part with some areas of the reef crest reaching 10-15 m water depth, notably in the vicinity of the modern Nereus reef near present sea-level. In contrast, the deepest parts of the inner platform are located in the southeastern area, where the bank is the widest (Fig. 3). In addition to this northwest-southe $\omega^{-t}$ asymmetry, reef crests of the northern and eastern leeward margins tend to be deeper (up to $60 \mathrm{~m}$ ate depth) and wider (up to $5 \mathrm{~km}$ wide) than those of the southern and western windward margit. which are located at 10 to $45 \mathrm{~m}$ water

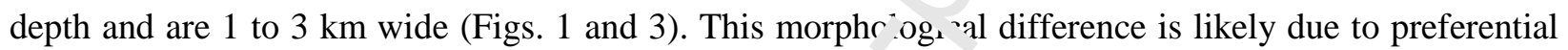
reef growth along the windward margins, as know from other locations (e.g. Yamano et al., 2003). In terms of spatial distribution of reefal morpholos as, reef crests and reef flats show alignments typically orthogonal but in places parallel to the ut $\mathrm{s}$ hank edge. Prominent pinnacle reefs, up to $20 \mathrm{~m}$ high, are common in back reef settings, but are ?lso sparsely present within the inner platform (Fig. 3). Although the bathymetric coverage is lin iter on the bank top because of the restricted swath width in shallow waters, there is an appareı. lack of discontinuities throughout the reef rims (such as inlets), as well as internal channels, sandy shoals/dunes or any obvious current-related bedforms on the platform top. However, outer reef morphologies are almost absent in the southeastern part of the bank, most likely due to the large-scale bank margin collapses and slope failures affecting that area (see section 3.5 and discussion).

\subsection{Bank top modern sediments}


As a first order sedimentary facies analysis of platform top environments, sediments have been described from eight cores distributed along two transects crossing the platform margin, from back reef to outer reef settings (KL06 to KL09 and KL02 to KL05; Fig. 2), and in deep inner platform settings, with one core (KL03) in the center of the bank (Fig. 2). The two core transects reveal similar patterns. Back reef environments are characterized by medium-grained carbonate sands containing large benthic foraminifers (LBF) (Marginopora vertebralis, Amphistegina sp., Elpı :'ium limbatum, among others), few planktic foraminifers (such as Orbulina universa, Globigerino 'os ;acculifer), abundant echinoid spines, Halimeda, serpulids, bryozoa, coral and sponge $\mathbf{\omega}$ bris. Coarse-grained carbonate sands accumulated on the reef flat, forming a discontinuous sand ap. nn as seen on sparker data (Fig. 4). They exhibit a typical high-energy setting LBF associ tion uominated by Calcarina sp., associated with Amphistegina sp., miliolids, Quinqueloculina sp. Peneroplis sp. Bioclasts are represented by echinoid, sponge, and coral debris. The outer reef $\mathrm{e}_{.}{ }_{\mathrm{s}}$ : hits a LBF and bioclast association similar to the reef flat, and shows Calcarina, Amphistegi ı _..., Marginopora sp., miliolids, echinoid and sponge fragments. Deep inner platform settings $\left(\mathrm{K}^{\mathrm{r}} \mathbf{0}^{2}\right)$ are characterized by the deposition of carbonate mud with abundant planktic foraminifers. Con $_{\iota_{\mathfrak{L}}}$ ared to reef settings, LBF are very rare (dominated by Amphistegnia sp.), and sponge and mollusc fragments are abundant.

\subsection{Bank top stratigraphy}

Although we primarily focus on surface geomorphology data in this paper, an interpretation of the seismic line crossing all the platform from northwest to southeast is proposed (Fig. 4). This line images the shallow sedimentary cover of the bank, up to $125 \mathrm{~ms}$ two-way-time (twt) at the maximum, corresponding approximately to $125 \mathrm{~m}$ of sediments (considering an average sound velocity of $2000 \mathrm{~m} / \mathrm{s}$ 
given the likely porous and unconsolidated nature of carbonate sediments on the platform top; Kenter et al., 2002). On reef rims, seismic penetration is only half of that, largely due to their higher impedance compared to unconsolidated carbonate sands and mud of inner platform settings. Based on reflection geometries, main unconformities and seismic facies variability, three main seismic units are distinguished (Fig. 4B). The deepest seismic unit, U1, is poorly imaged and comprises the acoustic "basement". Reflections are discontinuous and their overall geometry is difficult th econstruct and interpret. U1 is topped by a very irregular truncation surface (S1), typified by clear sh ped incisions up to $60 \mathrm{~ms}$ twt deep (ca. $60 \mathrm{~m}$ deep). Such incisions are mainly localized in he shallower, northern part of the bank whereas $\mathrm{S} 1$ is rather paraconformable in the southwestern $r$.rt , $f$ the bank. The limited number and wide spacing of profiles do not allow a precise mapnin ? of uils surface between lines, but it is likely to be polygenic (i.e. comprising several phases of er ion and infill). Seismic unit U2 is located above this surface and comprises variable seismic $\mathrm{f} \mathrm{cj}$ is from high to moderate amplitude, well-stratified reflections subparallel to $\mathrm{S}$, to more localizec, n- derate to low amplitude, chaotic to mounded reflections, possibly corresponding to reefs. Towards the southeastern part of the bank, where no clear angular unconformity is seen, U2 displays a signit $`$ nt thickening and is $c a .100 \mathrm{~ms}$ twt thick $(c a .100 \mathrm{~m})$ at the minimum. The associated asymmetric depocenter is located at the location of the deepest part of the present day bathymetry, possibly suggesting that it corresponds to a former inner platform infill and that reflection dips are depositional. However, a tectonic origin of depositional dips cannot be excluded, but the limited seismic coverage does not allow to choose between the two assumptions. Finally, U2 is delimited at its top by a clear and widespread sub-planar unconformity (S2) evidenced by erosional truncations, located at a depth below seafloor comprised between 100-150 ms twt ( $c a$. 100-150 m deep). The uppermost unit, 
U3, also thickens towards the inner platform in the southern part of the bank. It comprises three main seismic facies: (F3.1) high to moderate amplitude, highly bedded tabular reflections (mud-prone heterolithic intervals, as suggested by core KL03); (F3.2) transparent to faintly bedded, low amplitude tabular reflections (likely representing coarse-grained bioclastic sand intervals); and (F3.3) moderate to low amplitude, mounded, chaotic to faintly bedded reflections (likely representing reefs). This uppermost unit comprises the outer reef rim structures visible on bathymetry as $v^{\circ} \cdot 1$ as isolated pinnacles. Despite the poor seismic imaging below outer reef rims, seismic reflection an $\downarrow$ facies on the platform edge suggest that modern reefs were initiated on top of S2.

\subsection{Marine terrace}

Of particular note on both the swath bathyr try and seismic data is the presence of a 100 to 200 $\mathrm{m}$ wide, flat bathymetric zone, consistently $\operatorname{loc}^{+}{ }^{+e}$ between $65-70 \mathrm{~m}$ water depths on the present day fore-reef, directly seaward of the reci ist (Fig. 5). This "terrace" surrounds the bank almost continuously, apart from the south $\mathrm{rn}$ rea where a significant portion of the uppermost slope and bank edge collapsed (see following su tir ns) and hence the terrace is missing. Figure 5 shows that the terrace is characterized by a very ‘'ear seismic reflector, possibly in the stratigraphic continuity of the S2 unconformity, at around $100 \mathrm{~ms}$ twt ( $c a .100 \mathrm{~m}$ deep). However, seismic imaging through reefs is very poor and the two unconformities S1 and S2 are both very close to each other on the bank margin. Seismic data also show that the terrace is overlain and/or composed of a wedge-shaped layered unit (Fig. 5D), which is composed coarse-grained skeletal sands as revealed by gravity core KL-05.

\subsection{Slope physiography}


The Lansdowne Bank outer margins show three main domains: (i) a very steep upper slope with angles of repose ranging between $50^{\circ}$ to $20^{\circ}$, typically between the bank edge at 50-60 $\mathrm{m}$ and $\mathrm{ca}$. 300-400 $\mathrm{m}$ water depth; (ii) a rapidly decreasing middle slope with angles ranging from $20^{\circ}$ to $5^{\circ}$, typically comprised between $c a$. 300-400 and $500 \mathrm{~m}$; and (iii) a lower slope progressively flattening with a decrease in slope angle from $5^{\circ}$ to less than $1^{\circ}$ from $500 \mathrm{~m}$ deep down to basinal settings (Fig. 6). In terms of typography, such steep slope profiles point to an escarpment margin ' the bypass margin type of James and Mountjoy (1983). In the northe $\eta \mathrm{r}$ argin, upper slope profiles are even steeper and can locally reach angles of up to $75^{\circ}$ on the for s-reef that remain steep down to $1000 \mathrm{~m}$ water depth, i.e. in this particular area no transition to a sn other middle slope is seen on the data acquired during SEDLAB. Such steep slope profile are iikely due to a NW-SE normal fault affecting the Fairway Ridge basement in this area and delimı 'ng the northeastern edge of the Lansdowne Bank (Fig. 3), as interpreted on vintage seismic pro le; Mignot, 1984). In terms of slope morphologies, the western margin of the bank is marked by ar ua ' canyon heads (Figs. 2 and 7), all ending at the bank edge to form convex bank-ward embayments for ming a scalloped margin geometry, sensu Mullins and Hine (1989). Canyon heads are markea hy tributary, straight to low sinuosity gullies separated by diamond-shaped interfluves. Partly buried isolated blocks, up to $600 \mathrm{~m}$ in diameter/maximum length and up to $100 \mathrm{~m}$ high, are present within interfluve areas (Fig. 7). On the northern slope, where slope gradients are steeper, the configuration is similar with canyon heads reaching at the bank edge, yet their downdip continuation was not mapped by the SEDLAB cruise. On the southern and eastern slopes, spectacular bank edge and intraslope failures have been imaged, and are associated with slope gullies, low sinuosity channels/canyons, notably in the updip continuity of the Lansdowne Canyon. 


\subsection{Bank margin collapses and slope failures}

We document in this section the large-scale bank margin collapses and slope failures of the southern and eastern margins of the bank, respectively facing the Fairway and the New Caledonia basins (Fig. 8). These gravity collapses affect the bank margin over more than $50 \mathrm{~km}$ and are expressed on bathymetric data by mass transport complexes (MTCs) composed of failure scars on the bank edge and slope, and of fallen blocks and debris on the slope. The latter are spreac sver almost $600 \mathrm{~km}^{2}$ and can be located on the lower slope up to $10 \mathrm{~km}$ away from the bank edge, yet $\mathrm{c}$-eir majority is concentrated one to five kilometers away from the bank edge. We use the term "blo k" to represent coherent, outsized debris with dimensions in the order of several hundreds of meters. 'Ne tescribe MTCs in areas labelled A to D in a counterclockwise sense around the bank (Fig. (), sturting in the south. Their main morphological parameters are compiled into Table 1 . Failure sca s are evidenced by up to $20 \mathrm{~km}$-long arcuate headscarps on the bank edge and slope (Table 2). $\mathrm{X}_{\boldsymbol{u}}$ for area A where a single headscarp occurs, other areas shows complex morphologies witt st eral headscarps located at different depths of the bank edge and slope. Some are very superficiaı an $r$ affect the shallowest parts of the bank edge (typically between $60 \mathrm{~m}$ to $100 \mathrm{~m}$ water depths; he. tscarps $\mathrm{B} 1$ and $\mathrm{C} 1$; Table 2). However, these shallow scarps are parallel to more prominent headscarps located within the upper to middle slopes, typically between 100 and $400 \mathrm{~m}$ water depths (headscarps B2 and C2; Fig. 8). Of particular note is that all these shallow headscarps affect the terrace morphology identified elsewhere around the bank at $c a .70 \mathrm{~m}$ water depth. Deeper headscarps have been also imaged (B3, B4, C3 and C4), and are located at more variable depths on the middle to lower slopes (Fig. 8; Table 2). All scarps are spatially associated with blocks and debris, most of them being located in depositional areas on the middle to lower slope. However, in some places, blocks and 
debris are not spatially associated with fresh headscarps, neither on the bank edge nor on the slope (Fig. 7C). Their shapes vary from angular to smooth and from elongated to sub-rounded, whereas their dimensions range from a few 10s of meters in diameter/maximum length for the smallest imaged debris and up to $1 \mathrm{~km}$ for the most prominent blocks. Blocks can reach maximum heights of up to $150 \mathrm{~m}$ whereas debris are only a few meters to a few tens of meters high.

Area A is marked by a single headscarp (headscarp A, mappea ì green on Figs. 8 and 9) that is $21 \mathrm{~km}$ long, around $340 \mathrm{~m}$ high and which affects a significant portiol. of 'ne margin, from the bank edge at $60 \mathrm{~m}$ and the upper slope down to $400 \mathrm{~m}$ water depth. Asso iated debris occur in front of the failure scar on a debris field extending from the base of the upper $\mathrm{slo}_{\mathrm{f}}$ e over the middle to lower slope section. Debris are typically subrounded and less than $200 \mathrm{r}$ 'ters in diameter, yet subrounded or elongated bigger blocks are present. We note that debris are almu ${ }^{t}$ absent in a continuous trough-shaped zone along the headscarp (Fig. 9A). The area is also typ fi \& 4 hy tributary slope gullies, occurring both within and outside the MTC, that merge further dov nsı ne into the submarine channels of the northern Fairway Basin described by Rouillard et al. ( 2117 and Pattier et al. (2019). Outside the debris field, to the west of the depositional area, gullies $\mathrm{e}_{\mathrm{\imath}}{ }^{\mathrm{t}}$ on the lower slope at $c a .450 \mathrm{~m}$ water depth, whereas they reach the base of the upper slope at around $300 \mathrm{~m}$ close to the western edge of headscarp A and within the debris field. Gullies are v-shaped, up to $15 \mathrm{~m}$ deep and up to 200 meters wide. Adjacent to the western edge of headscarp A, the bank edge displays a slightly deeper terrace (labeled "Future failure area?" on Fig. 9A). On the bank top, the outer reef rim is not collapsed but the reef crest displays specific geometrical patterns, with 4-6 km-long, arcuate reef alignments facing the present day slope (Fig. 9B). 
Area B is more complex, with a source area that comprises at least four headscarps affecting the bank edge and the slope over around $20 \mathrm{~km}$ (Fig. 8). It comprises a shallow headscarp between $60 \mathrm{~m}$ and $100 \mathrm{~m}$ deep (headscarp B1, mapped in black in Figs. 8 and 9), which follows the main headscarp in the upper slope between 100-300 m (headscarp B2, mapped in yellow on Figs. 8 and 9). Deeper, secondary headscarps are present on the middle to lower slope between 300 to 550 m water depth (headscarps B3 and B4, mapped in purple and blue respectively on Figs. 8 and 9). F."'en debris and blocks are more heterogeneous in size than in area A and occur within the upper. $\mathrm{n}_{\mathrm{L}}$ : $\mathrm{dd} \mathrm{e}$ and lower slopes. Outsized, coherent angular blocks can be found downslope a few kilomete from the bank edge, along with smaller sized debris (Fig. 9C). The MTC depositional area is crosser: by slope gullies but also by wider (up to 400 $\mathrm{m}$ wide) and deeper (up to $80 \mathrm{~m}$ deep) low sinu sity unannels that are tributaries of the Lansdowne Canyon (Figs. 1 and 8). Blocks and debris are nt particularly funneled within channels and, in some places, are partly buried on interfluve c cers (Fig. 9D). The updip extremity of gullies and channels are hard to determine confidently, but t hey seem to be located on the middle slope, in the debris field. Finally, on the lower slope, isolated $s_{c^{1}}{ }^{1}-s$ zale arcuate scarps occur, suggesting local slide scars on that portion of the slope. The external ${ }_{t}{ }^{1}$ attorm and the outer reef rim display bank edge parallel alignments of reef morphologies and are significantly affected by headscarps, since the entire fore-reef and reef crest have collapsed (Fig. 9D). This indicates that the pre-failure(s) location of the bank edge was located seaward at a distance of at least the reef crest's width at that location.

Area $\mathrm{C}$ also comprises several headscarps affecting both the bank edge and the slope. Similarly to area B, a very shallow headscarp (C1, mapped in black in Figs. 8 and 10) affects the bank edge between 60 and $100 \mathrm{~m}$ water depths, and follows a deeper headscarp located between 100-350 $\mathrm{m}$ on the upper 
slope (headscarp C2, pink in Figs. 8 and 10). In turn, the middle slope is affected by a wider headscarp C3, between 350-500 m water depths. The two latter headscarps form the the present-day bank-ward embayment at that location but the deepest portions of the imaged lower slope comprise an even deeper, partly imaged scarp (C4, red in Figs. 8 and 10). In the proximal depositional area of the MTCs, debris and blocks are again heterogeneous in size and shape but, contrary to area B, are rare on the upper slope. On the middle slope, contained within $\mathrm{C} 3$, a distinct cluster of angular to ''ongated, outsized (up to $1 \mathrm{~km}$ long) coherent block distributed following an arcuate area facing the $\mathrm{s}_{1}$ nne stands out (Fig. 10A and B). A similar cluster of outsized coherent blocks is present further to ${ }^{\prime}$ ' northwest, but differs from the former as being located outside of the sidewall of C3. Here, som - $\mathrm{o}_{1}$ the blocks have a smoother appearance, suggesting partial burial by slope and hemipelagic dim nts. Another morphological feature in this area is an arcuate canyon head reaching the middle s, rpe in the southeastern part of the MTC (Fig. 10A and B). On the bank top, the shallowest $h: a r s " r p s(C 1$ and $C 2)$ visibly impact the distribution of reef morphologies, as a change in the o ien 'tion of reef alignments is observed, with reef alignments oriented orthogonally to the headscarps ind not orthogonally to the likely straighter pre-failure orientation of the bank edge). In addition, a s: ohtly deeper (up to $70 \mathrm{~m}$ deep) linear area throughout the reef rim is observed towards the canyon head, possibly suggesting erosion and/or preferential offbank sediment transport along this axis (Fig. 10B).

Area D (Fig. 10C and D) is typified by prominent fallen blocks, again up to almost $1 \mathrm{~km}$ in diameter, within a portion of the slope that is still significantly affected by canyons and gullies, yet no evidence on surface data was found for any failure scars. These blocks are angular to subangular and crop out on the seafloor, but some have a much smoother surface than others, suggesting partial burial due to 
post-failure sediment blanketing (Fig. 10D). Scouring is observed around some blocks suggesting interaction with post-failure flows. Again, blocks are present within gullies and canyon interfluves areas. Of note is the rarity of smaller sized debris in that area. Contrary to area A and B, gullies are shallower (less than $5 \mathrm{~m}$ deep), u-shaped, straighter and more regularly spaced. Gully heads are consistently located at around $400 \mathrm{~m}$ water depth. Reefal morphologies on the external platform are continuous, and display clear alignments orthogonal to the bank edge (Fig. 10D).

\subsection{Volume estimations}

Estimating the volumes of material involved in the bank $m_{a}$ "gin collapses and slope failures implies to reconstruct the initial configuration of the bank edge and slv ${ }_{1}$ e before failure. Ideally, it would require a complete seismic imaging of MTCs, from the $:$ pıuximal source area down to their most distal depositional areas. Despite a lack of such a $a_{n}{ }^{2}$ 'set, we have undertaken a first-order estimation for individual failures, by reconstructing t ie re-failure" bathymetry of the bank margin, typically by extrapolating margin profiles locat ed 'irectly outside failure areas. The methodology is illustrated with the example of area C (Fig. 11), vh re the pre-failure bank margin and slope were reconstructed based on bathymetric profiles locatc.' north and south of the failure scars. Subsequently, the elevation difference between the reconstructed pre-failure bathymetry and the present day bathymetry within the mass transport complex highlights material loss in the headscarp and depletion areas, as well as material gain in depositional areas (Fig. 11) and allows estimating the volume of displaced material. For area C, this single failure involves approximately $3 \mathrm{~km}^{3}$ of material. For areas B and A, the uncertainty in the prefailure slope reconstruction are greater but our estimates indicated volumes in the order of a few $\mathrm{km}^{3}$ (Table 1). Such volumes are similar to slope failures reported in similar settings, such as the margin and 
slope failures of southwestern Great Bahama Bank (Jo et al., 2015), the Great Barrier Reef mixed margin

(Puga-Bernabéu et al., 2017; 2020) or the SW Indian Ocean isolated platforms (Counts et al., 2018).

\section{DISCUSSION}

\subsection{Transport and depositional processes within MTCs}

The seafloor variability revealed by our acoustic data suggests diverse transport and depositional processes. Within the documented MTCs, the size, angular shape, $\mathrm{d}_{1}$ ibution over a relatively short distance from the bank edge of most debris and blocks suggest that her have been emplaced by mass slides (sensu Mulder and Cochonat, 1996), most likely rock - valanching processes derived from the brittle failure of early lithified material from the bank edge anc'or the slope. Depending on the origin of the margin collapses, at least part of the rock avlanciung and debris emplacement could have been subaerial. Clear trends are lacking in the downs, ne distribution of debris and blocks size, yet outsized coherent blocks tend to be located closf $\mathrm{r}^{+} \mathrm{u}$ the source area than smaller sized debris. This distribution suggests little longitudinal disinte! rai $n$ of fallen blocks into smaller sized debris and points to rapid freezing of the rock avalanche. Tre possible presence of curved failures planes at depth indicated by distinct headscarps at difte $\cdot$ ent levels along the margin profile, might also suggest translational sliding and/or rotational slumping processes. However, the lack of sufficient subsurface imaging that would reveal the overall geometry of failure planes and relationships with associated deposits do not allow us to discriminate between these mass slide processes. The distal end of most MTCs is not covered by our swath data (MTCs of areas B and C) thus it is difficult to apply the Skempton ratio (maximum headscarp height to slide length ratio; Skempton and Hutchinson, 1969) that is typically used to discriminate slides from slumps. However, in area A, the entire slide length is likely imaged and the failure plane is almost 
entirely evacuated (as suggested by the debris-free trough morphology along headscarp A; Fig. 9) and indicates a ratio of 0.017 , which points to a translational slide. That said, the ubiquity of debris and blocks in our study area and the absence of more homogeneous, depositional areas of displaced sediments (such as depositional cones or lobes) could potentially favor a dominance of rock avalanching over the slump, slide and debris flow processes. Again, the lack of data on the distal ends of MTCs limits the discussion on flow processes and notably the possible longitudinal transformati $r$ from proximal mass slides to cohesive debris flows and turbidity currents, as documented in other s.hm .rine landslides (e.g. Lastras et al., 2005). Apart from headscarps and blocks, no other clear kı'ematic indicator (e.g. Bull et al., 2009) that would allow further discussion on transport and deforr.at $\urcorner n$ processes are available for our current dataset. Blocks do not exhibit any preferential orier ation, except an along slope orientation of elongated blocks. The arcuate cluster of blocks of area D I oriented in the opposite direction to that of headscarps $\mathrm{C} 1, \mathrm{C} 2$ and $\mathrm{C} 3$. In some places, elong te $\lrcorner$ hlocks may correspond to extensional ridges separated by normal faults grabens (Fig. 9A).

Along with mass slides. $b_{j}$ na's morphologies such as slope gullies, low sinuosity channels and

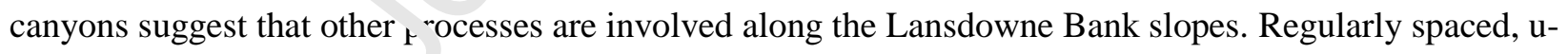
shaped straight gullies (Fig. 10C), with heads consistently located at around $400 \mathrm{~m}$ water depth, disconnected from the bank edge, could point to erosional, dense plunging currents (i.e. density cascading processes; see Wilson and Roberts, 1995; Betzler et al., 2014) in the eastern, leeward, margin of the Lansdowne Bank. In contrast, the less regularly spaced, v-shaped tributary gullies with heads located at different water depths, such as those of the southern windward slope of the Lansdowne Bank (Fig. 9A), as well as the low sinuosity channels and canyons of areas B and C (Figs. 9 and 10), could rather be initiated 
by slope failures and/or downslope eroding gravity flows. They would propagate upslope by retrogressive headward erosion as classically documented in siliciclastic, carbonate and mixed settings (Farre et al., 1983; Pratson and Coakley, 1996; Puga-Bernanéu et al., 2011; Mulder et al., 2012b; Tournadour et al., 2017). The presence of isolated, small scale slope failure scars is consistent with this interpretation (Fig. 9C). Within v-shaped gullies, the internal crescentic bedforms (Fig. 9A) are likely to correspond to the "cyclic steps" documented in the literature (e.g. Cartigny et al., ?914) indicative of downslope supercritical flows. While we do not rule out the fact that these erc ion $\_$pathways could be initiated and/or be influenced later in their evolution by other sedimenta.: processes such as offbank transport or along slope currents, a more comprehensive discussio ${ }^{*}$ the sedimentary dynamics along the Lansdowne Bank slopes is beyond the scope of this : ape 1 and our dataset.

Brittle carbonate margin collapse and slope $1_{c}$ ilure resulting in outsized blocks emplacement has been reported on modern carbonate platforms, ru ably along Bahamian slopes, such as the northern slope of

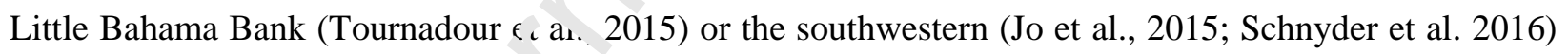
and northwestern slopes of Gre + B ahama Bank (GBB, Mulder et al., 2012a; Principaud et al., 2015; Le Goff et al., 2020). In the ca. 9 of northwestern GBB, the main headscarps of MTCs are located on the uncemented fine-grained slope and the run-out distances of blocks are greater than in our case study. The margin collapse documented by Jo et al. (2015) is more comparable to those presented in our study, since the upper cemented portion of the slope is affected and results in the deposition of elongated fragments of collapsed margin, as well as slide/slumps scars and channels on the middle and lower slope sections. Similarly, the examples of scalloped margin geometries of modern isolated carbonate platforms exist on the Nicaraguan rise (Mullins and Hine, 1989; Hine et al., 1992) but we are unaware of details morpho- 
bathymetrical studies on those banks. In mixed carbonate-siliciclastic settings, the submarine landslides reported along the Great Barrier Reef (GBR) are also comparable, notably the Viper Slide (Webster et al., 2016) and the Bowl Slide (Puga-Bernabéu et al., 2020). These submarine landslides indeed comprised multiple headscarps located both on the shelf edge and on the slope, and depositional areas dominated by fallen debris located close to the source area. Debris avalanching and translational sliding were the main mass movements invoked (Puga-Bernabéu et al., 2020).

\subsection{Age constraints}

Keys to the discussion on the likely absolute age of mass w. sting events as well as the possible role of relative sea-level fluctuations as a main triggering for $\operatorname{iar}_{\varsigma^{2}}$-scale collapses around the Lansdowne Bank lie in (i) the age of the onset of coralgal reef sposiuon on the Lansdowne Bank, and in (ii) the age and origin of the terrace identified at $c a .70 \mathrm{~m}$ a ound the bank. Indeed, numerous bank edge collapses affect these morphologies, and determ air $\mathrm{i}_{\mathrm{z}}$ their age would thus provide a minimum age for MTC emplacement as well as hints on thi ir i ming relative to sea-level changes. Regarding the former point, the onset of coralgal reef depositic o l the Lansdowne Bank remains poorly constrained. Past studies on barrier reefs such as the i ustralian GBR (Peerdeman and Davies 1993; Webster and Davies, 2003; Humblet and Webster, 2017), Florida Keys barrier reef (Multer et al. 2002), the Belize barrier reef (Droxler and Jorry, 2013), and New Caledonian barrier reef (Cabioch et al. 2008; Montaggioni et al. 2011) suggest that modern reef communities are inherited from the MIS11 sea-level transgression and the subsequent highstand, at $c a .400 \mathrm{ky}$ BP. Based on these global and regional constrains, as well as on our first-order seismic stratigraphy, we could argue that the onset of coralgal reef development begun during MIS 11 on the Lansdowne Bank and would be marked on seismic data by the S2 erosional unconformity 
(Figs. 4 and 5) onto which present day reefs may have initiated. Following that hypothesis, the reef sequences imaged on our seismic data (purple units within U3, Fig 4), may represent stacked reef units separated by subaerial exposure surfaces, during middle and upper Quaternary interglacial/glacial cycles. The last reef edifice, evidenced on both seismic and bathymetric data (Figs. 3, 4 and 5), would have been deposited during the last post-glacial sea-level rise. However, an alternative hypothesis would be to consider a more recent, MIS2 to Holocene post-glacial origin for the er ire reef sequence of seismic Unit 3 deposited onto the erosional surface S2, which would in this case r, nre ,ent exposure associated to the Last Glacial Maximum (LGM, Waelbroeck et al., 2002; Yokoy 'ma et al., 2000, 2018). This hypothesis could be consistent with the overall thickness of seismic U? ${ }^{2}$ w. ${ }^{-i}$ ch is less than $50 \mathrm{~m}$ thick, notably when comparing to overall thicknesses of drilled post-gl cial sef sequences of the GBR (see Webster et al., 2018). However, this hypothesis does not rult nut that coralgal reef growth begun during MIS 11, possibly onto the S1 polygenic erosional ur . r rformity, or deeper in the stratigraphy that is not imaged by our sparker seismic.

Regarding the age and origin $\mathrm{c}$ the terrace located at $c a .70 \mathrm{~m}$ water depth around the bank, many examples in the literature 4 scribed submerged terraces at 70-80 m water depth range around the world's Pleistocene carbonate platforms, such as the reef platform of Martinique (Leclerc et al., 2015), the drowned banks of the Texas shelf edge (Khanna et al., 2017), isolated carbonate platforms of the Mozambique Channel (Jorry et al., 2016), the Maldives (Fürstenau et al., 2010; Rovere et al., 2018), the Bahamas (Rankey and Doolittle, 2012), the GBR (Hinestrosa et al., 2014), among many others. Because rates of Quaternary sea-level changes are typically outpacing tectonic related vertical movements, Late Pleistocene submerged reef terraces are often interpreted as reflecting glacio-eustatic variations and 
subsequent sea-level changes (Woodroffe and Webster, 2014). Indeed, they are thought to reflect periods of stable sea level ("stillstands"), or decreased sea-level rise (e.g. Blanchon and Jones, 1995) or, on the contrary, periods of increased sea-level rise that lead to reef backstepping (Khanna et al., 2017). Similarly to the onset of coralgal reef deposition, the origin and age of the particular terrace located at $70 \mathrm{~m}$ water depth is contentious, as it could be either linked to glacial lowstands of the Pleistocene where relative sealevel was several times at ca. $80 \mathrm{~m}$ below that of the present day (e.g. ^ 1 IS 6; Rohling et al., 2017), or, alternatively, to much younger events during the last deglacial, such as ner ods of decreased sea-level rise before and after meltwater pulse 1A (e.g. Fairbanks, 1989; C.moin et al., 2004). In New Caledonia, several marine terraces have been identified on the outer $\mathrm{r} r$ et 'opes of the barrier reef (Flamand, 2006; Flamand et al., 2008), including a widespread ma ine wrrace at $c a .70-80 \mathrm{~m}$ water depth which was indirectly attributed to MIS 11 by correlation wiı. harrier reef sequences (Flamand, 2006; their T3 marine terrace). If that age is valid in our case, $\uparrow \mathrm{i}$ might confirm that the S2 unconformity, onto which the modern reef would have initiated on the Lansdowne Bank, dates back to $400 \mathrm{ka}$ and that the marine terrace is a morphological relic of $t$, he associated topography. However, the fact that no other terraces are preserved around the Lansi'vwne Bank might actually suggest that the terrace was rather formed during the last climatic cycle, yet it may also suggest that the Bank experienced significant reshaping of its slopes during the Late Quaternary. Moreover, the fact that this terrace did not experience any southern tilt as suggested by previous studies and by the overall deepening of the inner platform towards the south, could be due to a relative tectonic stability of the Bank during the last $400 \mathrm{ky}$ BP but could also be an additional argument to say that the terrace records more recent events (e.g. deglacial-Holocene stillstands). Therefore, given our dataset, it appears difficult to confidently determine whether the terrace 
is attributed to Pleistocene lowstands and would have been destabilized at any time subsequently, or if it is much younger, possibly from latest Pleistocene or early Holocene, thus suggesting that MTCs where triggered more recently during the last relative sea-level rise. The latter interpretation would be consistent with the relative "freshness" of MTCs related seafloor features, such as failure scars and associated fallen debris fields.

\subsection{Relative timing between MTCs}

The occurrence of multiple headscarps at different levels of the ba. ${ }^{1} e^{\prime}$ ge and slope suggests multiple failure events rather than a single catastrophic collapse, but th- relative timing of such events remains hard to determine. Without any seismic imaging or data or the nature and age of blocks and their postfailure cover, it is difficult to confidently deter ine ule exact chronology of MTCs emplacement. However, indirect evidence allows us to infer th. relative timing between MTCs such as (i) presence of uncovered, "fresh" headscarps; (ii) presє ac: of sharp, angular outsized blocks contrasting with smoothed and partly buried blocks; (iii) colla pst or modification of the spatial distribution of reefs on the external platform; and finally (iv) the cu'larse of the bank-scale terrace located at $c a .70 \mathrm{~m}$ water depth. On the basis of these criteria, the nargin segment from areas A to $C$ of the southern margin (Figs. 9 and 10) located updip of the Lansdowne Canyon in the New Caledonia Basin and updip of the smaller scale channels and gullies of the northern Fairway Basin (Rouillard et al., 2017) seems to be the most recent affected segment. On the contrary, in area D and along western slope canyons, fallen blocks are not related to any fresh headscarps on the slope or on the bank edge. Their overall smoother character (suggesting burial under post-failure sedimentation) together with the presence of the terrace along the bank edge at $c a .70 \mathrm{~m}$ water depth and an intact outer reef rim (suggesting post-slide reef growth; see next 
section) following the present day bank edge suggest that these blocks originate from older events than those operating in areas A to C.

\subsection{Impact of margin collapses on bank top morphologies}

Our data show that the shallow headscarps may result in a collapse of the external reef rim of the

Lansdowne Bank (as seen in area B; Fig. 9D). Moreover, bank margin collapse significantly reshapes the geometry of the bank edge and affects post-failure reef growth, as "iggested by the distribution of constructive reef morphologies within the reef crest, that, in some plac s. $r$. eferentially developed parallel to failure scars (see area C; Fig. 10B). At other places, where pa.tly buried fallen blocks on the slope and bank edge embayments suggest old mass wasting events, th - it. . $g e d$ outer reef rim structures run parallel to the bank edge (Figs. 7 and 10D) and point to $\mathrm{F}$ st-lailure reef growth along the newly shaped bank edge. More speculatively, the specific reef distr. 'Ition patterns imaged on the reef crest follows arcuate structures facing the slope (Fig 9B.), ar $d n^{\prime}$ mark old slide scars that would have been preserved by subsequent reef development. Inde d, . npographic highs and breaks of the basement substrate are known to be preferential zones for reeı tevelopment (Camoin and Webster, 2015; Esker et al., 1998; Woodroffe and Webster, 2014). Simi 'rities between these reef crest arcuate structures and landslide scars are convincing in terms of scales, position at the bank edge, orientation relative to the present day slope and overall morphology. However, this interpretation implies that the bank edge was located further inside the bank and would require significant bank progradation to reach the present day bank edge position. Alternatively, such arcuate structures might rather be related to fracture/dissolution features (see section 5.4.1). In any case, we believe that post-slide reef growth is a strong argument to discuss the relative timing of the emplacement of the different MTCs and submarine canyons imaged around the Lansdowne 
Bank. Similar post-slide reef growth around failure scars was also documented and used as an argument to discuss the age of the Viper slide on the GBR (Webster et al., 2016). In our case, some MTCs predate the development of the bank wide external reef rim at 40-50 $\mathrm{m}$ water depth as well as the terrace feature at ca. 60-70 m (e.g., slides from the western margin or eastern slope), whereas others post-date both the external reef rim and the terrace (slides from the southern margin).

\subsection{Emplacement mechanisms, preconditioning factors and trig ${ }_{\odot}$ rs of MTCs}

The emplacement mechanisms as well as controlling and preco diti sning factors of mass wasting events in carbonate settings are diverse and vary, from slope versteepening beyond angle of repose (Cook et al., 1972; Adams and Kenter, 2014), sedimen+ ov rloading (Ginsburg et al., 1991), fluid overpressure (Spence and Tucker, 1997), to di cerenual compaction and presence of preferential detachment surfaces (Malone et al., 2001). 1, nical triggers include increased sedimentation rates, tsunamis and storm waves, bottom cu re 1 s ctivity leading to increased surface shear stress on the seafloor, as well as tectonic activ ty :nd earthquakes (e.g. Austin et al., 1988; Schlager et al., 1988; Payros et al., 1999; Jo et al., 20,5: I Vunsch et al., 2017; Tournadour et al., 2017). Globally, the absence of in situ measurements ani precise stratigraphic constraints tend to limit discussions on all these mechanisms. However, in this section, we tentatively discuss the possible controls for the large-scale submarine failures occurring along the Lansdowne Bank, notably slope re-sedimentation processes, relative sea-level falls, as well as other possible external triggers. Finally, we provide a conceptual model for the MTCs emplacement which likely results from the interplay of these parameters.

\subsubsection{Slope oversteepening and platform early fracturing}


Carbonate slopes are steeper than their siliciclastic counterparts due to reef aggradation/progradation, early submarine cementation and compositional variations (Cook et al., 1972; Grammer et al., 1993; Adams and Kenter, 2014). Thus, intrinsic slope oversteepening is a key preconditioning factor for mass wasting events, which act as slope re-adjustment processes when the slope angle is higher than the angle of repose (i.e. equilibrium profile). The latter is in turn controlled by the interplay of several factors, from sediment composition and fabric (Kenter, 1990) to microbial processes 'Reolid et al., 2014). In our case study, the steep to very steep slope profiles of the Lansdowne Bank ' $\mathrm{Ol}^{\prime} \mathrm{d}$ be a strong preconditioning

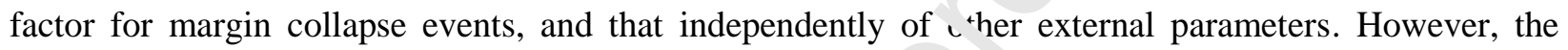
diversity of slope features around the bank, with a clear spa ${ }^{*}$ al . nk with erosional features, might suggest that slope re-sedimentation processes are also inve veu within MTCs (see next section). Among other processes that could lead to oversteepening and u-dercutting of the slope profile are contour currents (e.g. Betzler et al., 2014; Tournadour et al., 2 J1, 'Vunsch et al., 2017, 2018). However, no clear along slope current indicators such as scours, f irr 'vs or sandwaves have been imaged around the Lansdowne Bank. Another significant preconditio.ins, factor on margin collapses is the development of syn-depositional margin parallel fractures $a_{v}$ the platform margin as documented in ancient rimmed carbonate platforms (Frost and Kerans, 2009; McNeill and Eberli, 2009; Nooitgedacht et al., 2018) or proposed in numerical modeling experiments (Nolting et al., 2018; 2020). These fractures are proposed to be gravity driven and/or related to differential compaction and are believed to have a key role in gravitational collapses which, in turn, maintain sub-vertical reef walls. Although no such fractures are evident on our data, the arcuate reef structures of the reef crest as well as platform parallel reef alignments (Figs. 9A and 9B) might indicate ancient neptunian dikes formed by fracturing and karstic dissolution during subaerial 
exposure at sea-level lowstands. Of note is that very similar arcuate reef structures are seen along the present-day reef of New Caledonia, along "Blue Holes", which are likely to be karstic caves formed on margin parallel fractures as proposed for the Bahamas (Smart et al., 1988; Flügel, 2010).

\subsubsection{Retrogressive headward erosion of slope morphologies}

In our case study, the margin collapses and slope failures that are still exposed on the seafloor are spatially associated with erosional morphologies, including slope $\mathrm{gu}_{1}{ }^{1}{ }_{2} \mathrm{~s}$, low sinuosity channels and canyons (Figs. 7 to 10). Furthermore, the margin collapse and slope f: $: 1$ ur s of areas B and C are located on the headscarp domain of the deep Lansdowne Canyon (Figs. and 8). A simple mechanism that could thus be significantly involved in the generation of bar' c a collapses and slope failures is the retrogressive headward erosion of these features. fre $\mathrm{n}$ luw er to upper slope and bank edge environments. Such process is indeed frequently involved in $\mathrm{t}_{1}$ ` genesis and evolution of slope canyons (Farre et al., 1983; Pratson and Coakley, 1996; Puga B ‘ `béu et al., 2011; Mulder et al., 2012b; Tournadour et al., 2017) as well as in the evolution o la. dslides (Gardner et al., 1999). Similar to the models proposed by Puga-Bernabéu et al. (2011) On th Great Barrier Reef and to that of Tournadour et al. (2017) for the northern slope of Little Ba' 'ama Bank, one could consider that MTCs were emplaced following a four stage evolution proess during which retrogressive erosion prevails, with (i) inception of small scale failures, gullies and channels on the lower and/or middle slopes; (ii) updip propagation of slope gullies and channels, during which coalescent slides can be triggered on the middle to upper slope sections, possibly due to higher slope gradients or at any other geological weakness forming a preferential detachment surface (e.g. Harwood and Towers, 1988); (iii) formation of a proper canyon head when coalescent slides merge, forming "deep" headscarps, as observed in our data; and ultimately (iv) canyon 
headward propagation by successive retrogressive sidescarp and headscarp failures reaching the upper slope and bank edge, resulting in shallow headscarps, margin collapse and destabilization of the platform edge and outer reefs. The configuration of the western part of area A (Figs. 9A and B) could be consistent with such interpretation, notably when considering the distribution of gully heads, which get closer to the bank edge as getting closer to the failure area. However, this simple scenario would imply that most

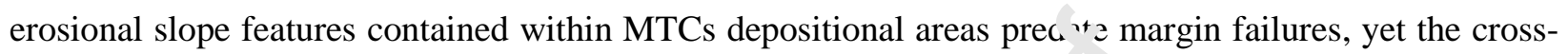
cutting relationships between failure headscarps, fallen debris anc slr pe erosional features do not necessarily concur with that statement. Although debris and bloc's are not preferentially contained within erosional talwegs and erosional pathways are not deviated or 1 . nneled by blocks and debris (Figs. 9, 10 and 11), in many places partly buried blocks are $\mathrm{F} \cdot$ ese $ı$ within interfluves areas of submarine canyons (Figs. 7, 9 and 10). Rather this latter observatı - would indicate that failures predate the formation of erosional pathways within the debris fic d`. Tonsequently, other mechanisms than retrogressive erosion are thus highly likely to interplay ir th oeneration of MTCs around the Lansdowne Bank.

\subsubsection{Relative sea-level}

The relationships bet, 'een relative sea-level fluctuations and mass wasting processes around carbonate platforms remain unclear. Periods of low relative sea-level have been yet suggested as having an indirect role in the triggering and/or preconditioning of slope failures, since they can result in platform exposure, erosion, weathering, dissolution and pore fluid overpressure release (Spence and Tucker, 1997), or in the generation of preferential detachment surfaces due to early diagenesis (Malone et al., 2001). They can also have a direct genetic link, by gravitational instability, where significant rock falls along carbonate sea cliffs occur during relative sea-level lowstands and sea-level rise, resulting in talus breccia 
deposition (Grammer and Ginsburg, 1992). Similarly, Aby (1994) highlighted the role of wave undercutting at the base of carbonate sea cliffs during lowstands, platform-parallel fractures developed during emersion, block deposition at the base of cliff and, ultimately, margin retreat. Wunsch et al. (2017, 2018) demonstrated that slope failures of the northern part of the leeward slope of Great Bahama Bank were correlated with lowering of the sea-level from the last glaciation. However, other case studies suggested that slope failures and gravity-related sedimentation was als $`$ active during relative sea-level rise and highstand (e.g. Grammer et al., 1993; Reijmer et al., 2012; 20. 5). ' Jn the GBR, Puga-Bernabéu et al. (2017) and Webster et al. (2016) suggested that the Viper a.' Gloria slides occurred during relative sea-level rise, during the last deglacial sea-level rise for the fon ar and during the MIS12-11 for the latter. In terms of mechanisms, increased hydrostatic p" ssuı on upper slope sediments was suggested as triggering calcidebris flows during relative sea-ı vel rises (Andresen et al., 2003; Lantzsch et al., 2007). In our case study, considering the presf at $u$ ' $v$ water depth of the Lansdowne Bank at less than $100 \mathrm{~m}$ deep and assuming negligible tectını movements over the Quaternary along the Lord Howe Rise and Fairway Ridge, the platform $w_{a}-\mathrm{u}$ idoubtedly totally emerged during Middle/Late Pleistocene sea-level lowstands. Indeed, the $c a$. $120 \mathrm{~m}$ sea-level fall of the LGM would have led to a complete platform exposure, margin parallel fracturation at the platform edge, platform-top karstification, as well as the development of a subaerial sea cliff prone to destabilization by wave undercutting and gravitational instability.

\subsubsection{Other possible external triggers}

Apart from episodic intraplate volcanic activity during the Tertiary (Exon et al., 2004; Van de Beuque et al., 1998), the area is considered as being tectonically inactive since at the least the Eocene (Collot et 
al., 2008; Rouillard et al., 2017) and therefore tectonic related slope oversteepening is unlikely. However, recent seismic activity reported in the vicinity of the Lansdowne Bank does not allow us to rule out the fact that failures could have been seismically triggered. Indeed, the worldwide network gathered in the USGS database reports a few events with a magnitude $>4$ close to the southern Lansdowne Bank and the Lansdowne Canyon, suggesting presence of a small cluster of earthquakes between the Fairway Ridge and the New Caledonia Basin, roughly aligned along 20.5 $\mathrm{S}$ (as noted ir Pillet and Pelletier, 2005; their fig. 5). In 2002 , a 5.7 earthquake was recorded at $20.52^{\circ} \mathrm{S} 162.18^{\circ} \mathrm{E}$ ( ${ }^{7} \mathrm{ig}$. 1). The passage of a storm and its associated hydrostatic loading and wave hammering are knc vn to have the potential to trigger slope failures (e.g. Rogers and Goodbred, 2010) and the Lans low ne Bank is located in an area exposed seasonally to tropical cyclones, notably between the hot ald wet season from January to April. The most superficial failure headscarps in our study area - cur between $60-100 \mathrm{~m}$ of water depth and could have been triggered by oscillating pressures $\mathrm{d} / \mathrm{ri} \mathrm{s}$ $\mathrm{ct}$.orm wave propagation. In addition, the windward position of the destabilized margin with $\mathrm{reg}_{ } \mathrm{ra}_{\llcorner}{ }^{+} \mathrm{o}$ trade winds, as well as its orientation facing dominant swells is possibly another external trigg.r. inally, as several potential sources of fluid have been suggested, notably fluids of diagenetic rrgin (Pattier et al., 2019), fluid escapes are another potential trigger that can be speculated to be involved, notably when considering several indirect indications documented in the Fairway Basin, such as polygonal faulting or pockmarks, but these would tend to affect all bank margins in the same way.

\subsubsection{Conceptual depositional model}

Figure 12 schematic cartoons aim at explaining the formation of the documented MTCs of the Lansdowne Bank, where several mechanism/controlling factors interplay, during a cycle of relative sea- 
level fluctuation. In this scheme, we consider a stable slope during relative sea-level highstand with maximum aggradation as the initial state (stage 1). Erosional slope morphologies such as gullies, channels and canyons can be present along the lower slope, and can originate from various processes (e.g. retrogressive headward propagation from initial lower slope failures, downslope eroding turbidity currents or density cascading processes (Wilson and Roberts, 1995; Betzler et al., 2014). Following that initial stage, in the absence of age constraints, we consider two alternative sc arios for the relative timing of margin collapses and slope failures with regard to relative sea-level flı - tu $\cdot$.tions. In the former alternative (stages $2 \mathrm{a}$ and 3a), margin collapses and slope failures are believ to essentially occur during relative sea level fall. Stage 2a involves exposure of the platforr ^, argin fracturing and neptunian dikes, karstification, and development of an erosional se clin that will be prone to subaerial rock fall. This stage would result in the accumulation of a rock - all-dominated debris field and outsized coherent blocks from early lithified material shed from s' al'c v headscarps on the bank edge and upper slope regions (e.g. B1, B2, C1, C2; Figs. 8, 9 and 10). Du -ing that stage, lower slope erosional morphologies could progress upslope due to retrogressive $h t . d w$ ard progagation. Stage $3 a$ corresponds to the onset of slope failures, still during low relative sea 'evel, possibly due to overloading on the upper and middle slopes, and/or due to continued upslope migration of erosional morphologies, resulting in deeper headscarps on the lower portions of the slope (e.g. B3, C3; Figs. 9 and 10). However, the associated submarine rock avalanches would affect mud prone material and could evolve into more cohesive erosional debris flows that could also initiate channel and gully systems within the MTCs depositional area. In the second alternative (stages $2 \mathrm{~b}$ and $3 \mathrm{~b}$ ), we consider that margin collapses and slope failures are essentially triggered during relative sea level rise, which would be consistent with a deglacial-Holocene origin for the destabilized 
marine terrace (see section 5.2). Stage $2 \mathrm{~b}$ considers a similar configuration to that of stage $2 \mathrm{a}$, with platform exposure, karstification and fracturing, as well as upslope propagation of slope morphologies. However, we consider more limited margin failures and subaerial emplacement of fallen debris and blocks on the upper slope, at the base of the erosional sea cliff. Stage $3 \mathrm{~b}$ corresponds to a relative sealevel rise which will result in coeval submarine slope failures and margin collapses, possibly due to increased hydrostatic pressure on the upper slope debris sheets and ba. ${ }^{1}:$ edge sediments, as well as by wave undercutting during transgression. Similarly to stage $2 b$, gullies a nd hannels within the debris field might originate from downslope eroding flows sourced from sı ne failures, yet we do not rule out again that they could also be formed by retrogressive headward $\mathrm{pr}\lrcorner \mathrm{pa}_{c}$ tion. Finally, Stage 3 is common to both scenarios and considers the configuration at $h$ in inative sea-level, similar to the present day configuration, with post-slide reef development a'ong shallow failure headscarps, and possibly enhanced platform to basin sediment transfers due to 4 - destabilization of external reefs. Note that karstic features and open fractures are likely to se :lled at that stage, possibly resulting in the arcuate and linear geometries of the present day re $f^{\prime} c^{\prime}$ est.

\subsection{Tsunamigenic poı ntial}

The potential of submarine landslides to produce devastating tsunamis in purely carbonate or mixed carbonate-siliciclastic settings is comparatively less documented than in subaerial or other marine settings, but has been addressed by modeling in recent studies in the Bahamas and in the Great Barrier Reef (Schnyder et al., 2016; Webster et al., 2016; Puga-Bernabéu et al., 2020). In this study, due to the proximity of the Lansdowne Bank to the inhabited main island of New Caledonia, the tsunami potential of the Lansdowne Bank MTCs was assessed. An individual MTC was selected, the one of area C, where 
the source and depositional area are best imaged by our data (Figs. 8 and 10). Input parameters were derived from bathymetric data and geological settings. The center of mass has been located at $161.3^{\circ} \mathrm{E}$; $20.5^{\circ} \mathrm{S}$; the measure of the main headscarp provided an along-slope length of the slid mass of $7000 \mathrm{~m}$, a thickness of ca. $500 \mathrm{~m}$ and an across-slope width of $2000 \mathrm{~m}$, corresponding to a total volume of $7 \mathrm{~km}^{3}$. The slope angle has been estimated to be $36.6^{\circ}$ and the distance travelled by the center of mass to $4000 \mathrm{~m}$. A bulk density of $2700 \mathrm{~kg} \cdot \mathrm{m}^{-3}$ has been chosen for the collapsed mater. ${ }^{1}$., corresponding to consolidated carbonate sediments. The modelled azimuth has been chose to $\mathrm{N} 70^{\circ}{ }_{1}$ ag eement with the orientation of the submarine landslide deposits. The propagation was compuı $d$ with a time step of $0.8 \mathrm{~s}$ during 7200 time steps, i.e. $\sim 1$ h30. Figure 13 shows the tsunami travel inıs and maximum wave heights which are around $10 \mathrm{~m}$ in the vicinity of the slide region corr polıung to the maximum water elevation reached in each $500 \mathrm{~m}$ by $500 \mathrm{~m}$ cell of the domain during $\backsim e$ whole propagation. Two important implications arise from our tsunami simulations. First, is th ₹ r $\mathcal{c}^{\cdot 1 \text { ity }}$ of the Lansdowne Bank landslides to produce a tsunami able to reach New Caledonia coas iin $300 \mathrm{~km}$ away from the source within 35 minutes, as shown on Figure 13. Second, due to the d. ner sive effect, the maximum wave height at the New Caledonia shoreline is considerably smaller that the wave height in the source area (which is around $10 \mathrm{~m}$ ). Of note is that the tsunami initial amplitude is strongly influenced by the slide behavior (speed, cohesion, run-out distance, etc.), thus the values shown here must be considered with care. In addition, it must be noted that the modelling has been performed considering the present day sea-level, and a smaller water depth would have significant consequences on our simulations. Nevertheless, the $500 \mathrm{~m}$ resolution of the D.E.M. is precise enough to include the New Caledonia lagoon and indicates that the amplitude of the wave due to the shoaling effect when entering the lagoon increases by a factor 2 to 3 (from $0.5 \mathrm{~m}$ in the open ocean to 
1-1.5 $\mathrm{m}$ at the external barrier). It shows also that the main tsunami amplitude is not located directly in the failure direction but prefers to follow shallow bathymetry zones like the Fairway Ridge toward the South, probably due to the dispersion effect at greater depths, corresponding in this area to the New Caledonia Basin. An accurate study of potential landslide sources as well as a mapping of actual landslide scars should be done in the future to better estimate this underrated hazard. Regarding the effects of the external barrier reef, recent studies on submarine landslides along the Great ? arrier Reef indicated that reefs would have a buffering effect on tsunami waves (Puga-Bernabéu et à' 2 J20). However, although these slides are similar in terms of volumes and geometry, in our ca ${ }^{`}$ study the distance between the source and the external barrier reef of New Caledonia is much gre ate and implies that only very energetic low frequencies would reach the New Caledonian reef Otıur studies demonstrated that, depending on the wave amplitude, wavelength and frequency, as $w-11$ as geometry and roughness of the reef, the latter can have an amplification effect on tsunami wrw (e.g. Kunkel et al., 2006; Fernando et al., 2008; Roger et al., 2014). In addition, other studie $\mathrm{su}_{i}$ gested that discontinuous barrier reefs (ie. with inlets), as it is the case in New Caledonia, lead to an a nplification of tsunami heights and increased run-ups directly in front of inlets (Gelfenbaum et .', 2011; Le Gal and Mitaraï, 2020). Therefore, the use of more detailed bathymetric data close to the shore, reproducing particularly the coral reef barrier and its openings, would help to conclude on the protective role (or not) of these features against tsunami waves triggered by landslides especially along the western coast of New Caledonia, a priori sheltered from tsunami triggered by earthquakes all around the Pacific Ocean according to past events analysis (Sahal et al., 2010; Roger et al., 2019). 


\section{CONCLUSIONS}

New geophysical and geological data acquired during the SEDLAB cruise in 2018 show that the

Lansdowne Bank is a partly drowned, isolated rimmed platform typified by diverse resedimentation processes along its edge and adjacent slopes evidenced by submarine canyons, channels and gullies. Surprisingly, no obvious sediment transfer axes across the reef rims (i.e. inlets), internal channels, tidal shoals or any clear current-related bedforms were imaged on the bank ${ }^{\dagger} \supset$ p. However, spectacular largescale margin collapses and slope failures have been imaged and a a sociated with $\mathrm{km}$-sized fallen blocks, forming chaotic debris fields at the base of slope. These 'ailures do not only destabilize the entire outer reef rim but possibly impact post-slide reef growth nn fffbank sediment transport. Determining preconditioning factors and triggering mechanisi`s tu such bank edge and slope failure remains somewhat speculative, however, we emphasize $l_{1}$ • potential role of relative sea-level fluctuations as well as retrogressive erosion processes, yet $\mathrm{h} f$, slative timing between slope morphologies and landslides remains unclear. External triggers suc: as seismic activity or oscillating waves during storm events are also envisaged. In any case, the no' sible interplay between margin collapse and slope bypass features is seen as a key parameter in he export of sediments from the isolated carbonate platform to the deepwater sedimentary basin. Finally, simplified modelling of the tsunamigenic potential of these submarine landslides suggests that mass wasting events should be taken into account when assessing natural hazards and risk in New Caledonia. 


\section{ACKNOWLEDGMENTS}

We thank the captain and crew of R/V Alis for their critical role in the success of the SEDLAB cruise (doi:10.17600/18000401). The French National Fleet is thanked for having facilitated the cruise with complementary financing from its cruise support fund, following proposition by the French National Commission for the High-seas Fleet (CNFH). We acknowledge journal editor Michele Rebesco, as well as reviewers John J.G. Reijmer, David Tappin and Angel Puga-Bernabe for their relevant comments on an earlier version of the paper.

\section{DATA REPOSITORY STATEMENT}

The bathymetric and seismic data from the SFDL. B cruise (conducted in 2018 onboard French R/V ALIS) upon which the present paper is based on - ill be made public 6 years after the cruise, and will be available through the online porta ol French Oceanographic Cruises following this link https://campagnes.flotteoceanographic le.fr ampagnes/18000401/index.htm. The doi of the cruise and its data is the following: doi:10.17600/18now ${ }^{1 n}$ : 


\section{FIGURE CAPTIONS}

Figure 1: A. Regional location map of the study area in the SW Pacific Ocean. NZ: New Zealand; PNG: Papua New Guinea; AUS: Australia. B. Location map of the Lansdowne Bank area, on the northern extremity of the Fairway Ridge and Lord Howe Rise, around $300 \mathrm{~km}$ away from New Caledonia (NC). Yellow circles correspond to earthquakes referenced by the USGS in the study area (magnitude >3). Grey scale map corresponds to global seafloor topography (Smith and Sandwell, 1997). C. Bathymetric map around the Lansdowne Bank, showing newly acquired multibeam data by the SEDLAB cruise onboard French R/V Alis as well as compiled data from past cruises (in bright colors). Background data (pale colors) corresponds to global seafloor ‘nography (Smith and Sandwell, 1997). The grey arrow indicates the updip part of the channel-lobe system w nented by Rouillard et al. (2017) and Pattier et al. (2019).

Figure 2: Overview of multibeam bathymetry (EM1002), ve-: nigh resolution seismic and sediment gravity cores acquired during the SEDLAB cruise. Locations of all fig" "es pruvided in this paper are indicated, as well as those of bathymetric profiles of Figure 6 (numbered from 1 、c,

Figure 3: A. Shaded bathymetric map onı wh ith only the shallow-water bathymetry $(<100 \mathrm{~m}$ deep) of the SEDLAB data has been color-coded t $\cap$. : ohlight the physiography of the bank top. Isobaths (10 $\mathrm{m}$ spacing) were tentatively drawn on the bank top hased on SEDLAB data and SHOM (French Naval Hydrographic and Oceanographic Service) navi atı maps. The dashed red line corresponds to the approximate position of the basement normal faults delimı ng the northern slope of the bank. B. Bathymetric profiles across the bank (location on Fig. 2) displaying its typical concave-up topography as well as a deepening of the inner platform and eastern leeward reef rim toward the southeast. Note also the narrower and shallower character of the western and southern windward reef rim compared to its leeward counterpart to the north and the east. Pi: Pinnacle reefs (circled on the map).

Figure 4: A. Very high resolution sparker seismic profile crossing the Lansdowne Bank from the NW to SE (location on Fig. 2). B. Line drawing interpretation of the above profile showing the first order stratigraphy imaged by the SPARKER comprising a poorly imaged, disrupted lower unit (U1, grey), a middle unit developed above a 
highly irregular truncating surface (S1, red) showing channelized geometries as well as a thick depocenter on the southeastern part of the bank (U2, orange) and finally an upper unit (U1, yellow) characterizing the present day configuration with outer reef rims and subtabular geometries in the inner platform, delimited from U2 by a subplanar erosional unconformity (S2, blue). C. Details of the two main erosional unconformities S1 and S2 and typical seismic character of seismic units. Note the truncation by S2 of the infills of the S1 incision(s). D. Details of the southeastern margin of the Bank showing the border of the depocenter of unit U2, possibly as constructive prograding features. Note the backstepping trend of reefal facies (in purple) within U1. F3.1, F3.2 and F3.3 are seismic facies (see text for their description).

Figure 5: 3D bathymetric views and sparker seismic profiles showing a c ontir lous, flat morphology interpreted as a submerged reef level at $c a$. 70-80 mbsl on the uppermost slope of ... La asdowne Bank, in fore reef environments. Note the possible correlation between the terrace and the S2 unc snı rmity in seismic data. Location of Figures A and $\mathrm{C}$ are provided on Fig. 2.

Figure 6: Slope bathymetric profiles from the bank c 'ge to the most distal extent of the SEDLAB data in key locations around the Lansdowne Bank, repre en tive of slope profiles in the different margins (see Fig. 2 for profile locations).

Figure 7: A. Close-up bathymetric na, on an arcuate canyon head along the western slope of the Lansdowne Bank B. Same area than A where $\left.\eta_{1}{ }^{4}{ }^{2}\right\lrcorner$ shallow water areas have been color-coded to highlight bank top morphologies, as well as the terrace at ca., $\mathrm{m}$ bordering the bank edge. C. Close-up bathymetric map on canyon heads close to Nereus reef, on the western slope of the Lansdowne Bank. Note the partly buried blocks on the slope, typically within canyon interfluves D. Same area than Fig. C with color-coding of the bank edge bathymetry only.

Figure 8: A. Bathymetric map of the southeastern part of the Lansdowne Bank, showing numerous gravitational features on the slope, including slope gullies, channels and canyons but also spectacular mass transport complexes. The latter are composed of slide scars evidenced by headscarps associated with fallen/transported blocks and debris. Locations of close-up figures 9 and 10 are provided. B. Surface morphological map showing erosional features (in 
green), blocks and debris (in red) as well as the main failure headscarps. For descriptive purposes, this area has been subdivided into four areas (from A to D).

Figure 9: A. Close-up bathymetric map on the western limit of area A. Note the spatial correlation between debris distribution and extent of headscarp A. B. Same area than A showing the distribution of reefal morphologies following arcuate alignments. C. Close-up bathymetric map on the southern part of area B, showing a complex source area with headscarps at different levels of the bank edge and slope, ahead of a channelised debris field (see text for details). D. Same area than C revealing a complete collapse of the ret ${ }^{\prime}$ crest by headscarps B1 and B2, as well as bank edge parallel reef alignments.

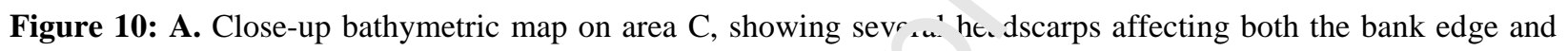
the slope, outsized (up to $1 \mathrm{~km}$ long) fallen blocks within an arcurte ' 'Ister contained with headscarp C2, as well as an individual canyon head reaching the upper slope sectinn. ... $\leqslant$ ame area than A showing post-slide growth of the reef crest, as well as potential evidence for prefer -ntic seciment transfer axis suggested by a deeper channelised area with fewer reefs oriented towards the cany'on head. Ientified on the slope. C. Close-up bathymetric map on area D, showing angular outsized blocks, linear sof guilies and a canyon head with dentritic internal gullies reaching the middle to upper slope, but without iny isible headscarps on the bank edge or slope. D. Same area than C showing bank edge perpendicular reef a $a^{\prime \prime}$ onments but a lack of evidence for failures on the bank edge.

Figure 11: Schematic diay. $n_{1}-1$. wing the simple methodology used to estimate volumes of material involved within individual mass trans $s_{\mathrm{p}}$ urt complexes (example of area $\mathrm{C}$ ). The pre-slide bathymetry was reconstructed by extrapolating slope profiles located immediately outside of the failure area. Uncertainty lies in the determination of the pre-failure location of the bank edge (i.e. distance "d"). The calculation of the elevation difference between the pre-slide bathymetry and the present day bathymetry highlights and quantify zones of "loss" or "gain" of material (cold to warm colors on the elevation difference maps, respectively).

Figure 12: A. Schematic conceptual models for the bank edge collapse and slope failures emplacement of the southern Lansdowne Bank during a cycle of relative sea level fluctuation. See discussion for details. 
Figure 13: Maximum tsunami wave heights map with an angle of failure $=70^{\circ}$ clockwise from North (symbolized by the black arrow). The red star indicates the landslide source. Thin black lines represents the tsunami travel times (TTT) with an interval of 5 minutes. 


\section{REFERENCES}

Aby, S.B., 1994. Relation of bank-margin fractures to sea-level change, Exuma Islands, Bahamas. Geology 22, $1063-$ 1066. doi:10.1130/0091-7613(1994)022<1063:ROBMFT>2.3.CO;2

Adams, E.W., Kenter, J.A.M., 2014. So Different, Yet so Similar: Comparing and Contrasting Siliciclastic and Carbonate Slopes, in: Verwer, K., Playton, T.E., Harris, P.M. (Mitch) (Eds.), Deposits, Architecture, and Controls of Carbonate Margin, Slope and Basinal Settings, SEPM Special Publication. SEPM Society for Sedimentary Geology, Tulsa, pp. 14-25. doi:10.2110/sepmsp.105.14

Andresen, N., Reijmer, J.J.G., Droxler, A.W., 2003. Timing and distribution of calciturbidites around a deeply submerged carbonate platform in a seismically active setting (Pedro Bank, Northern Nicaragua Rise, Caribbean Sea). Int. J. Earth Sci. 92, 573-592. doi:10.1007/s00531-003-0340-0

Austin, J.A., Ewing, J.I., Ladd, J.W., Mullins, H.T., Sheridan, R.E., 1988. Seismi : Stratigraphic Implications of ODP Leg 101 Site Surveys, in: Proceedings of the Ocean Drilling Program, 101 Scius ${ }^{-i f i c}$ Results, Proceedings of the

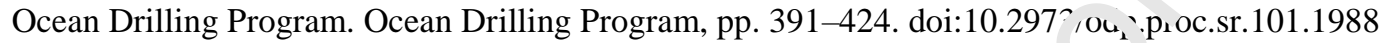

Auzende, J.-M., Bénéton, G., Dickens, G.R., Exon, N.F., François, C., Hodw׳nı, Juffroy, F., Lafoy, Y., Leroy, A., Van de Beuque, S., Voutay, O., 1999. ZONECO5 cruise,L'Atalante R/' '. do 10.17600/99010120

Betzler, C., Eberli, G.P., Kroon, D., Wright, J.D., Swart, P.K., Nath, B.N. Alvarez-Zarikian, C.A., Alonso-García, M., Bialik, O.M., Blättler, C.L., Guo, J.A., Haffen, S., Horozal, S., In sue, M., Jovane, L., Lanci, L., Laya, J.C., Mee, A.L.H., Lüdmann, T., Nakakuni, M., Niino, K., Petruny, L.M., H tiw , S.D., Reijmer, J.J.G., Reolid, J., Slagle, A.L., Sloss, C.R., Su, X., Yao, Z., Young, J.R., 2016a. The abrv'st Ol. at of the modern South Asian Monsoon winds. Sci. Rep. 6, 29838. doi:10.1038/srep29838

Betzler, C., Hübscher, C., Lindhorst, S., Lüdmann, T., Reij er, …G., Braga, J., 2016b. Lowstand wedges in carbonate platform slopes (Quaternary, Maldives, na. in C'ean). Depos. Rec. 2, 196-207. doi:10.1002/dep2.21

Betzler, C., Lindhorst, S., Eberli, G.P., Lüdmann, T., । ‘ ‘bius, J., Ludwig, J., Schutter, I., Wunsch, M., Reijmer, J.J.G., Hübscher, C., 2014. Periplatform drift: The c ^mbined . zsult of contour current and off-bank transport along carbonate platforms. Geology 42, 871-874. do1. ' $9.1130 /$ G35900.1

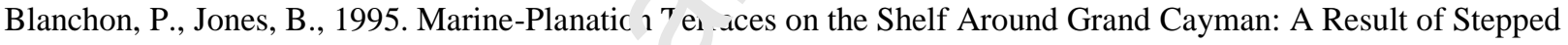
Holocene Sea-Level Rise. J. Coast. Res 11

Borgomano, J.R.F., 2000. The Upper Cr tau nus Carbonates of the Gargano-Murge Region, Southern Italy: A Model of Platform-To-Basin Transition. AA`'G Bull. 84, 1561-1588. doi:10.1306/8626BF01-173B-11D7$8645000102 \mathrm{C} 1865 \mathrm{D}$

Bosellini, A., Neri, C., Luciani, 'r., 19:2. Platform margin collapses and sequence stratigraphic organization of carbonate slopes: Cretac 'ous 'Eoc ne, Gargano Promontory, southern Italy. Terra Nova 5, 282-297. doi:10.1111/j.1365-3121.1, 3.tu00259.x

Bull, S., Cartwright, J., Huuse, ' '.., 2009. A review of kinematic indicators from mass-transport complexes using 3D seismic data. Mar. Pet. Geol. 26, 1132-1151. doi:10.1016/j.marpetgeo.2008.09.011

Cabioch, G., Montaggioni, L., Thouveny, N., Frank, N., Sato, T., Chazottes, V., Dalamasso, H., Payri, C., Pichon, M., Sémah, A.-M., 2008. The chronology and structure of the western New Caledonian barrier reef tracts. Palaeogeogr. Palaeoclimatol. Palaeoecol. 268, 91-105. doi:10.1016/j.palaeo.2008.07.014

Cabioch, G., Taylor, F.W., Récy, J., Edwards, R.L., Gray, S.C., Faure, G., Burr, G.S., Corrège, T., 1998. Environmental and Tectonic Influence on Growth and Internal Structure of a Fringing Reef at Tasmaloum (SW Espiritu Santo, New Hebrides Island Arc, SW Pacific), in: Reefs and Carbonate Platforms in the Pacific and Indian Oceans. John Wiley \& Sons, Ltd, pp. 259-277. doi:10.1002/9781444304879.ch14

Camoin, G.F., Montaggioni, L.F., Braithwaite, C.J.R., 2004. Late glacial to post glacial sea levels in the Western Indian Ocean. Mar. Geol. 206, 119-146. doi:10.1016/j.margeo.2004.02.003

Camoin, G.F., Webster, J.M., 2015. Coral reef response to Quaternary sea-level and environmental changes: State of the science. Sedimentology 62, 401-428. doi:10.1111/sed.12184 
Cartigny, M.J.B., Ventra, D., Postma, G., Berg, J.H. van D., 2014. Morphodynamics and sedimentary structures of bedforms under supercritical-flow conditions: New insights from flume experiments. Sedimentology 61, 712-748. doi:10.1111/sed.12076

Chen, Q., Kirby, J.T., Dalrymple, R.A., Kennedy, A.B., Chawla, A., 2000. Boussinesq Modeling of Wave Transformation, Breaking, and Runup. II: 2D. J. Waterw. Port Coast. Ocean Eng. 126, 48-56. doi:10.1061/(ASCE)0733-950X(2000)126:1(48)

Collot, J., Geli, L., Lafoy, Y., Vially, R., Cluzel, D., Klingelhoefer, F., Nouzé, H., 2008. Tectonic history of northern New Caledonia Basin from deep offshore seismic reflection: Relation to late Eocene obduction in New Caledonia, southwest Pacific. Tectonics 27. doi:10.1029/2008TC002263

Collot, J., Herzer, R., Lafoy, Y., Géli, L., 2009. Mesozoic history of the Fairway-Aotea Basin: Implications for the early stages of Gondwana fragmentation. Geochem. Geophys. Geosyst. 10, n/a-n/a. doi:10.1029/2009GC002612

Cook, H.E., McDaniel, P.N., Mountjoy, E.W., Pray, L.C., 1972. Allochthonous carbonate debris flows at Devonian bank ("reef") margins, Alberta, Canada. Bull. Can. Pet. Geol. 20, 439-497. d i $\cdot 10.35767 /$ gscpgbull.20.3.439

Cook, H.E., Mullins, H.T., 1983. Basin margin, in: Scholle, P.A., Bedout, D.G.. ${ }^{\wedge}$ noı C.H. (Eds.), Carbonate Depositional Environments, Memoirs of the American Association of Petro eum Jeologists. pp. 539-617.

Correa, T.B.S., Grasmueck, M., Eberli, G.P., Reed, J.K., Verwer, K., Purki ,, S., 2012. Variability of cold-water coral

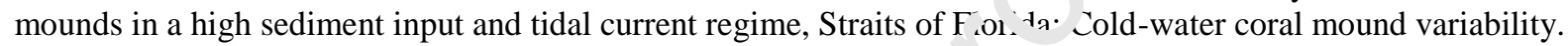
Sedimentology 59, 1278-1304. doi:10.1111/j.1365-3091.2011.01306.

Counts, J.W., Jorry, S.J., Leroux, E., Miramontes, E., Jouet, G., 201 Sec mentation adjacent to atolls and volcanocored carbonate platforms in the Mozambique Channel (SW Indian 'cean). Mar. Geol. 404, 41-59. doi:10.1016/j.margeo.2018.07.003

Counts, J.W., Jorry, S.J., Vazquez Riveiros, N., Jouet, G., C ra. der d, J., Cheron, S., Boissier, A., Miramontes, E., 2019. A Late Quaternary record of highstand shedr $\ldots . \mathrm{t}, \mathrm{m}$ an isolated carbonate platform (Juan de Nova, southern Indian Ocean). Depos. Rec. 5, 540-557 doi $0.10 \mathrm{v} 2 / \mathrm{dep} 2.57$

Droxler, A.W., Jorry, S.J., 2013. Deglacial Origin of Baı :er Reefs Along Low-Latitude Mixed Siliciclastic and Carbonate Continental Shelf Edges. Annu. Re、 Mar. Sci. 5, 165-190. doi:10.1146/annurev-marine-121211172234

Droxler, A.W., Schlager, W., 1985. Glacial verss s i iterglacial sedimentation rates and turbidite frequency in the Bahamas. Geology 13, 799-802. doi:1 113`/0091-7613(1985)13<799:GVISRA>2.0.CO;2

DTSI, 2009. Atlas bathymétrique de la i suve.ie-Calédonie. Direction des Technologies et des Services de l'Information, Service de la Géoma : 'uu et de la Télédétection, Gouvernement de la Nouvelle-Calédonie, Nouméa.

Eberli, G.P., 1991. Calcareous turhidı $\backsim$ nd relationship to sea level fluctuations and tectonism, in: Einsele, G., Ricken, W., Seilacher, A. (E ts.), Yycles and Events in Stratigraphy. Berlin, pp. 340-359.

Emery, K.O., Tracey, J.I., Ladu, H.د., 1954. Geology of Bikini and nearby atolls, Marshall Islands. USGS P. P. 1265.

Esker, D., Eberli, G.P., McNeill, D.F., 1998. The structural and Sedimentological Controls on the Reoccupation of Quaternary Incised Valleys, Belize Southern Lagoon1. AAPG Bulletin 82, 2075-2109. doi:10.1306/00AA7BE41730-11D7-8645000102C1865D

Etienne, S., Collot, J., Le Roy, P., 2018. SEDLAB cruise, Alis R/V. doi:10.17600/18000401

Exon, N.F., Quilty, P.G., Lafoy, Y., Crawford, A.J., Auzende, J.-M., 2004. Miocene volcanic seamounts on northern Lord Howe Rise: Lithology, age and origin. Aust. J. Earth Sci. 51, 291-300. doi:10.1111/j.14400952.2004.01058.x

Fairbanks, R.G., 1989. A 17,000-year glacio-eustatic sea level record: Influence of glacial melting rates on the Younger-Dryas event and deep ocean circulation. Nature 342, 637-641.

Farre, J.A., MGregor, B.A., Ryan, W.B.F., Robb, J.M., 1983. Breaching the Shelfbreak: Passage from Youthful to Mature Phase in Submarine Canyon Evolution, in: The Shelfbreak: Critical Interface on Continental Margins, SEPM Special Publication. pp. 25-39. 
Fernando, H.J.S., Samarawickrama, S.P., Balasubramanian, S., Hettiarachchi, S.S.L., Voropayev, S., 2008. Effects of porous barriers such as coral reefs on coastal wave propagation. J. Hydro-Environ. Res. 1, 187-194. doi:10.1016/j.jher.2007.12.003

Flamand, B., 2006. Les pentes externes du récif barrière de la Grande Terre de Nouvelle-Calédonie: morphologie, lithologie, contrôle de la tectonique et de l'eustatisme (Ph. D. Thesis). Univ. Bretagne Occidentale, Brest.

Flamand, B., Cabioch, G., Payri, C., Pelletier, B., 2008. Nature and biological composition of the New Caledonian outer barrier reef slopes. Mar. Geol. 250, 157-179. doi:10.1016/j.margeo.2007.12.002

Flügel, E., 2010. Microfacies of Carbonate Rocks: Analysis, Interpretation and Application, 2nd ed. Springer-Verlag, Berlin Heidelberg. doi:10.1007/978-3-642-03796-2

Frost, E.L., Kerans, C., 2009. Platform-Margin Trajectory as a Control on Syndepositional Fracture Patterns, Canning Basin, Western Australia. J. Sediment. Res. 79, 44-55. doi:10.2110/jsr.2009.014

Fürstenau, J., Lindhorst, S., Betzler, C., Hübscher, C., 2010. Submerged reef terraces of the Maldives (Indian Ocean). Geo-Mar. Lett. 30, 511-515. doi:10.1007/s00367-009-0174-2

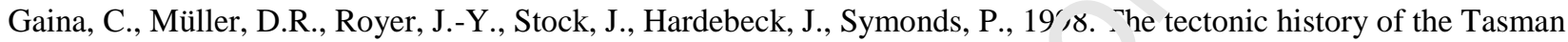
Sea: A puzzle with 13 pieces. J. Geophys. Res. 103, 12413-12433. doi:10.1 ?9/ 8JB00386

Gardner, J.V., Prior, D.B., Field, M.E., 1999. Humboldt Slide — a large sh ar-d minated retrogressive slope failure. Mar. Geol. 154, 323-338. doi:10.1016/S0025-3227(98)00121-2

Gelfenbaum, G., Apotsos, A., Stevens, A.W., Jaffe, B., 2011. Effects of ^ inging reefs on tsunami inundation: American Samoa. Earth-Sci. Rev. 107, 12-22. doi:10.1016/j.ears' rev 2010.12.005

Ginsburg, R.N., Harris, P.M., Eberli, G.P., Swart, P.K., 1991. T1 - yrowth potential of a bypass margin, Great Bahama Bank. J. Sed. Petrol. 61, 976-987. doi:10.1306/D426781B 2',2 -11D7-8648000102C1865D

Gischler, E., 2011. Sedimentary Facies of Bora Bora, F rw..'s Type Barrier Reef (Society Islands, South Pacific): The Unexpected Occurrence of Non-Skeletal Gr .ns. . Seaıment. Res. 81, 1-17. doi:10.2110/jsr.2011.4

Gischler, E., 2006. Sedimentation on Rasdhoo and Ari s; olls, Maldives, Indian Ocean. Facies 52, 341-360. doi:10.1007/s10347-005-0031-3

Glaser, K.S., Droxler, A.W., 1993. Controls an 11 veıpment of Late Quaternary Periplatform Carbonate Stratigraphy in Walton Basin (Northeastern N ic ragua Rise, Caribbean Sea). Paleoceanography 8, 243-274. doi:10.1029/92PA02876

Grammer, G.M., Ginsburg, R.N., 1992.' 'ighs. and versus lowstand deposition on carbonate platform margins: insight from Quaternary foreslopes in the ' ' 'ha. . .as. Mar. Geol. 103, 125-136. doi:10.1016/0025-3227(92)90012-7

Grammer, G.M., Ginsburg, R.N., Ha. 'is. ?.M., 1993. Timing of Deposition, Diagenesis, and Failure of Steep Carbonate Slopes in Respon e to High-Amplitude/High-Frequency Fluctuation in Sea Level, Tongue of the Ocean, Bahamas, in: Carı na` $\mathbf{s}$ ¿quence Stratigraphy: Recent Developments and Applications, AAPG Memoir. p. 131.

Hamylton, S.M., Duce, S., Vila-Concejo, A., Roelfsema, C.M., Phinn, S.R., Carvalho, R.C., Shaw, E.C., Joyce, K.E., 2017. Estimating regional coral reef calcium carbonate production from remotely sensed seafloor maps. Remote Sens. Environ. 201, 88-98. doi:10.1016/j.rse.2017.08.034

Handford, C.R., Loucks, R.G., 1993. Carbonate Depositional Sequences and Systems Tracts-Responses of Carbonate Platforms to Relative Sea-Level Changes, in: Loucks, R.G., Sarg, J.F. (Rick) (Eds.), Carbonate Sequence Stratigraphy: Recent Developments and Applications, AAPG Memoir. pp. 3-41.

Harris, D.L., Webster, J.M., De Carli, E.V., Vila-Concejo, A., 2011. Geomorphology and morphodynamics of a sand apron, One Tree Reef, Southern Great Barrier Reef. J. Coast. Res. 760-764.

Harwood, G.M., Towers, P.A., 1988. Seismic sedimentological interpretation of a carbonate slope, north margin of Little Bahama Bank, in: Proceedings of the Ocean Drilling Program, 101 Scientific Results, Proceedings of the Ocean Drilling Program. Ocean Drilling Program, pp. 263-277. doi:10.2973/odp.proc.sr.101.1988

Hine, A.C., Locker, S.D., Tedesco, L.P., Mullins, H.T., Hallock, P., Belknap, D.F., Gonzales, J.L., Neumann, A.C., Snyder, S.W., 1992. Megabreccia shedding from modern, low-relief carbonate platforms, Nicaraguan Rise. Geol. Soc. Am. Bull. 104, 928-943. doi:10.1130/0016-7606(1992)104<0928:MSFMLR>2.3.CO;2 
Hinestrosa, G., Webster, J.M., Beaman, R.J., Anderson, L.M., 2014. Seismic stratigraphy and development of the shelf-edge reefs of the Great Barrier Reef, Australia. Mar. Geol. 353, 1-20. doi:10.1016/j.margeo.2014.03.016

Humblet, M., Webster, J.M., 2017. Coral community changes in the Great Barrier Reef in response to major environmental changes over glacial-interglacial timescales. Palaeogeogr. Palaeoclimatol. Palaeoecol. 472, 216 235. doi:10.1016/j.palaeo.2017.02.003

James, N.P., Mountjoy, E.W., 1983. Shelf-slope break in fossil carbonate platforms: An overview, in: Stanley, D.J., Moore, G.T. (Eds.), The Shelf Break; Critical Interface on Continental Margins, SEPM Special Publication. SEPM, pp. 189-206.

Janson, X., Eberli, G.P., Lomando, A.J., Bonnaffé, F., 2010. Seismic Characterization of Large-Scale PlatformMargin Collapse Along the Zhujiang Carbonate Platform (Miocene) of the South China Sea, Based on Miocene Outcrop Analogs from Mut Basin, Turkey, in: Cenozoic Carbonate Systems of Australasia, SEPM Special Publication.

Jo, A., Eberli, G.P., Grasmueck, M., 2015. Margin collapse and slope failure alot ? southwestern Great Bahama Bank. Sediment. Geol. 317, 43-52. doi:10.1016/j.sedgeo.2014.09.004

Jorry, S.J., Camoin, G.F., Jouet, G., Le Roy, P., Vella, C., Courgeon, S., Prat, ؟ , Fot tanier, C., Paumard, V., Boulle, J., Caline, B., Borgomano, J., 2016. Modern sediments and Pleistocene $\sim 1 \mathrm{um}$ isolated carbonate platforms (Iles Eparses, SW Indian Ocean): A preliminary study. Acta Oecol., Île. Épa ses (French Scattered Islands, SW Indian Ocean) as reference ecosystems for environmental research. $\%$. 12y-143. doi:10.1016/j.actao.2015.10.014

Jorry, S.J., Droxler, A.W., Francis, J.M., 2010. Deepwater carbonate depe sition in response to re-flooding of carbonate bank and atoll-tops at glacial terminations. Quat. Sci. Ku- '9, 2010-2026. doi:10.1016/j.quascirev.2010.04.016

Jorry, S.J., Droxler, A.W., Mallarino, G., Dickens, G.R., Bent. ^, S J., Beaufort, L., Peterson, L.C., Opdyke, B.N., 2008. Bundled turbidite deposition in the central Pando. Trough (Gulf of Papua) since Last Glacial Maximum: Linking sediment nature and accumulation to sea eve fluc. dations at millennial timescale. J. Geophys. Res. 113, F01S19. doi:10.1029/2006JF000649

Jorry, S.J., Jouet, G., Edinger, E.N., Toucanne, S. Counts, J.W., Miramontes, E., Courgeon, S., Riveiros, N.V., Le Roy, P., Camoin, G.F., 2020. From platform top . ר adjacent deep sea: New source-to-sink insights into carbonate sediment production and transfer in the SW In $\lrcorner_{\perp} \cdot r$ Ocean (Glorieuses archipelago). Mar. Geol. 423, 106144. doi:10.1016/j.margeo.2020.106144

Kench, P.S., Thompson, D., Ford, M.R., J` 'wa, H., McLean, R.F., 2015. Coral islands defy sea-level rise over the past century: Records from a central ' 'acific atoll. Geology 43, 515-518. doi:10.1130/G36555.1

Kennedy, A.B., Chen, Q., Kirby, J.T., Da "ymple, R.A., 2000. Boussinesq Modeling of Wave Transformation, Breaking, and Runup. I: 1D. I ' $\mathbf{V}_{\mathfrak{a}} \cdots{ }^{*}$ w. Port Coast. Ocean Eng. 126, 39-47. doi:10.1061/(ASCE)0733950X(2000)126:1(39)

Kennett, J.P., von der Borch, C. . , et al., 1986. Site 587: Lansdowne Bank, Southwest Pacific, in: Initial Reports of the Deep Sea Drilling Proj $n$, 90, Initial Reports of the Deep Sea Drilling Project. U.S. Government Printing Office, pp. 115-138. doi:10.2973/dsdp.proc.90.1986

Kenter, J.A.M., 1990. Carbonate platform flanks: slope angle and sediment fabric. Sedimentology 37, 777-794. doi:10.1111/j.1365-3091.1990.tb01825.x

Kenter, J.A.M., Anselmetti, F.S., Kramer, P.H., Westphal, H., Vandamme, M.G.M., 2002. Acoustic Properties of "Young" Carbonate Rocks, ODP Leg 166 and Boreholes Clino and Unda, Western Great Bahama Bank. J. Sediment. Res. 72, 129-137. doi:10.1306/041101720129

Khanna, P., Droxler, A.W., Nittrouer, J.A., Tunnell Jr, J.W., Shirley, T.C., 2017. Coralgal reef morphology records punctuated sea-level rise during the last deglaciation. Nat. Commun. 8, 1046. doi:10.1038/s41467-017-00966-x

Kunkel, C.M., Hallberg, R.W., Oppenheimer, M., 2006. Coral reefs reduce tsunami impact in model simulations. Geophys. Res. Lett. 33, L23612. doi:10.1029/2006GL027892

Lafoy, Y., Brodien, I., Vially, R., Exon, N.F., 2005. Structure of the Basin and Ridge System West of New Caledonia (Southwest Pacific): A Synthesis. Mar. Geophys. Res. 26, 37-50. doi:10.1007/s11001-005-5184-5 
Lantzsch, H., Roth, S., Reijmer, J.J.G., Kinkel, H., 2007. Sea-level related resedimentation processes on the northern slope of Little Bahama Bank (Middle Pleistocene to Holocene). Sedimentology 54, 1307-1322. doi:10.1111/j.1365-3091.2007.00882.x

Lastras, G., Blasio, F.V.D., Canals, M., Elverhøi, A., 2005. Conceptual and Numerical Modeling of the BIG'95 Debris Flow, Western Mediterranean Sea. J. Sediment. Res. 75, 784-797. doi:10.2110/jsr.2005.063

Launay, J., Dupont, J., Lapouille, A., Ravenne, C., de Broin, C.E., 1977. Seismic traverses across the northern Lord Howe rise and comparison with southern part (South-West Pacific), in: International Symposium on Geodynamics in the Southwest Pacific. Presented at the International Symposium on Geodynamics in the Southwest Pacific, Technip, Paris, Noumea, pp. 155-163.

Le Gal, M., Mitarai, S., 2020. Reef influence quantification in light of the 1771 Meiwa tsunami. Ocean \& Coastal Management 195, 105248. doi:10.1016/j.ocecoaman.2020.105248

Le Goff, J., Slootman, A., Mulder, T., Cavailhes, T., Ducassou, E., Hanquiez, V., Jaballah, J., Reijmer, J.J.G., 2020. On the architecture of intra-formational Mass-Transport Deposits: Insights fr $r$ the carbonate slopes of Great Bahama Bank and the Apulian Carbonate Platform. Mar. Geol. 427, 106205. do.. ${ }^{10.1016 / j . m a r g e o .2020 .106205}$

Le Suavé, R., 1996. ZONECO4 cruise, L'Atalante R/V. doi:10.17600/9601008 )

Leclerc, F., Feuillet, N., Cabioch, G., Deplus, C., Lebrun, J.F., Bazin, S., B aua 'cel, F., Boudon, G., LeFriant, A., De Min, L., Melezan, D., 2014. The Holocene drowned reef of Les Saint $s_{r^{\prime}}{ }^{\prime a t r}$ au as witness of a long-term tectonic subsidence along the Lesser Antilles volcanic arc in Guadeloupe. Mar. Geol. 355, 115-135. doi:10.1016/j.margeo.2014.05.017

Leclerc, F., Feuillet, N., Perret, M., Cabioch, G., Bazin, S., Lebrun, '.-1 Saurel, J.M., 2015. The reef platform of Martinique: Interplay between eustasy, tectonic subsidence ... ${ }^{7}$ volcanısm since Late Pleistocene. Mar. Geol. 369 , 34-51. doi:10.1016/j.margeo.2015.08.001

Lüdmann, T., Betzler, C., Eberli, G.P., Reolid, J., Reij ... - J.' G., Sloss, C.R., Bialik, O.M., Alvarez-Zarikian, C.A., Alonso-García, M., Blättler, C.L., Guo, J.A., Haf en, '., Horozal, S., Inoue, M., Jovane, L., Kroon, D., Lanci, L., Laya, J.C., Mee, A.L.H., Nakakuni, M., Nath, B.N., Viino, K., Petruny, L.M., Pratiwi, S.D., Slagle, A.L., Su, X., Swart, P.K., Wright, J.D., Yao, Z., Young, J.. . 2018. Carbonate delta drift: A new sediment drift type. Mar. Geol. 401, 98-111. doi:10.1016/j.margeo.2018.04.n11

Lüdmann, T., Kalvelage, C., Betzler, C., Fürsten u, ,., Hübscher, C., 2013. The Maldives, a giant isolated carbonate platform dominated by bottom currents IN. r. I et. Geol. 43, 326-340. doi:10.1016/j.marpetgeo.2013.01.004

Luyendyk, B.P., 1995. Hypothesis for Cietac nus rifting of east Gondwana caused by subducted slab capture. Geology 23, 373-376. doi:10.113C'0u’1-7613(1995)023<0373:HFCROE>2.3.CO;2

Malone, M.J., Slowey, N.C., Hende ' on, J.M., 2001. Early diagenesis of shallow-water periplatform carbonate sediments, leeward margin, r,rea Banama Bank (Ocean Drilling Program Leg 166). Geol. Soc. Am. Bull. 113, 881-894. doi:10.1130/0 '16- ' 506 2001)113<0881:EDOSWP>2.0.CO;2

McNeill, D.F. and Eberli, G.P., ' 2 109. Early Load-Induced Fracturing in a Prograding Carbonate Margin. In: Perspectives in Carbonate Luology: A Tribute to the Career of Robert Nathan Ginsburg (Eds P.K. Swart, G.P. Eberli and J.A. McKenzie), Int. Assoc. Sedimentol. Spec. Publ. 41, pp. 327-336.

Mignot, A., 1984. Sismo-stratigraphie de la terminaison nord de la ride de Lord Howe. Evolution géodynamique du Sud-Ouest Pacifique entre l'Australie et la Nouvelle-Calédonie (Thèse de Doctorat de 3ème Cycle). UMPC.

Missègue, F., Lafoy, Y., Le Suavé, R., Van de Beuque, S., Henin, C., Grandperrin, R., Perrier, J., 1998. Campagne ZoNéCo-04, 22 septembre au 12 octobre 1996, Rapport final, Interprétation des données (No. 4), Travaux du Groupe Zone Economique de Nouvelle-Calédonie. ORSTOM, Nouméa.

Montaggioni, L.F., Cabioch, G., Thouveny, N., Frank, N., Sato, T., Sémah, A.-M., 2011. Revisiting the Quaternary development history of the western New Caledonian shelf system: From ramp to barrier reef. Mar. Geol. 280, 5775. doi:10.1016/j.margeo.2010.12.001

Mortimer, N., Campbell, H.J., Tulloch, A.J., King, P.R., Stagpoole, V.M., Wood, R.A., Rattenbury, M.S., Sutherland, R., Adams, C.J., Collot, J., Seton, M., 2017. Zealandia: Earth's Hidden Continent. GSA Today 27-35. doi:10.1130/GSATG321A.1 
Mortimer, N., Dadd, K.A., O’Toole, L., Crundwell, M., Seton, M., Williams, S., Etienne, S., Collot, J., 2019. Eocene nephelinite and basanite from the Fairway Ridge, North Zealandia. Deep Sea Res. Part I Oceanogr. Res. Pap. 152, 103101. doi:10.1016/j.dsr.2019.103101

Mulder, T., Cochonat, P., 1996. Classification of offshore mass movements. J. Sediment. Res. 66, 43-57. doi:10.1306/D42682AC-2B26-11D7-8648000102C1865D

Mulder, T., Ducassou, E., Eberli, G.P., Hanquiez, V., Gonthier, E., Kindler, P., Principaud, M., Fournier, F., Leonide, P., Billeaud, I., Marsset, B., Reijmer, J.J.G., Bondu, C., Joussiaume, R., Pakiades, M., 2012a. New insights into the morphology and sedimentary processes along the western slope of Great Bahama Bank. Geology 40, 603-606. doi:10.1130/G32972.1

Mulder, T., Ducassou, E., Gillet, H., Hanquiez, V., Tournadour, E., Combes, J., Eberli, G.P., Kindler, P., Gonthier, E., Conesa, G., Robin, C., Sianipar, R., Reijmer, J.J.G., François, A., 2012b. Canyon morphology on a modern carbonate slope of the Bahamas: Evidence of regional tectonic tilting. Geology 40, 771-774. doi:10.1130/G33327.1

Mullins, H.T., Cook, H.E., 1986. Carbonate apron models: Alternatives to the subma -ine fan model for paleoenvironmental analysis and hydrocarbon exploration. Sediment. Geol. 48, . 7-79. doi:10.1016/00370738(86)90080-1

Mullins, H.T., Heath, K.C., Buren, H.M.V., Newton, C.R., 1984. Anatomy of a lodern open-ocean carbonate slope: northern Little Bahama Bank. Sedimentology 31, 141-168. doi:10.1: 1 1/j.1 565-3091.1984.tb01956.x

Mullins, H.T., Hine, A.C., 1989. Scalloped bank margins: Beginnins of $t_{1} \geqslant$ end for carbonate platforms? Geology 17 , 30-33. doi:10.1130/0091-7613(1989)017<0030:SBMBOT>2.3.C`’?

Multer, H.G., Gischler, E., Lundberg, J., Simmons, K.R., Shinr, , _ A., 2002. Key Largo Limestone revisited: Pleistocene shelf-edge facies, Florida Keys, USA. Facies 4 个 22 ) -271. doi:10.1007/BF02668083

Münch, Ph., Cornee, J.-J., Lebrun, J.-F., Quillevere, F ' Jourdan, F., Lardeaux, J.-M., De Min, L., Letice J.-I ., Randrianasolo, A., 2014. Pliocene to Pleistocene vertical movements in the forearc of the Lesser Antilles sub 'iction: insights from chronostratigraphy of shallow-water carbonate platforms (Guadeloupe archipelag, J. Geol. Soc. 171, 329-341. doi:10.1144/jgs2013-005

Nolting, A., Zahm, C.K., Kerans, C., Alzayer, ${ }^{v}$., $? 0_{\llcorner}$? . The influence of variable progradation to aggradation ratio and facies partitioning on the development of sy ıuepositional deformation in steep-walled carbonate platforms. Mar. Pet. Geol. 114, 104171. doi:10.10’ o/j mau petgeo.2019.104171

Nolting, A., Zahm, C.K., Kerans, C., Nil oliı. kou, M.A., 2018. Effect of carbonate platform morphology on syndepositional deformation: Insights :-om numerical modeling. J. Struct. Geol. 115, 91-102. doi:10.1016/j.jsg.2018.07.003

Nooitgedacht, C.W., Kleipool, I .M., Andeweg, B., Reolid, J., Betzler, C., Lindhorst, S., Reijmer, J.J.G., 2018. New insights in the developm ${ } \mathrm{t}^{\mathrm{c}} \mathrm{c}^{\mathrm{s}} \mathrm{sy}$-depositional fractures in rimmed flat-topped carbonate platforms, Neogene carbonate complexes, Sorba Basin, SE Spain. Basin Res. 30, 596-612. doi:10.1111/bre.12239

Pattier, F., Etienne, S., Collot, ., Patriat, M., Tournadour, E., Roest, W.R., Rouillard, P., 2019. Neogene-Quaternary architecture and sedimentary processes on an isolated carbonate-fed deep-water basin (Fairway Basin, Southwest Pacific). Mar. Geol. 413, 27-47. doi:10.1016/j.margeo.2019.04.003

Payros, A., Pujalte, V., Orue-Etxebarria, X., 1999. The South Pyrenean Eocene carbonate megabreccias revisited: new interpretation based on evidence from the Pamplona Basin. Sediment. Geol. 125, 165-194. doi:10.1016/S00370738(99)00004-4

Pedoja, K., Husson, L., Johnson, M.E., Melnick, D., Witt, C., Pochat, S., Nexer, M., Delcaillau, B., Pinegina, T., Poprawski, Y., Authemayou, C., Elliot, M., Regard, V., Garestier, F., 2014. Coastal staircase sequences reflecting sea-level oscillations and tectonic uplift during the Quaternary and Neogene. Earth-Sci. Rev. 132, 13-38. doi:10.1016/j.earscirev.2014.01.007

Peerdeman, F.M., Davies, P.J., 1993. Sedimentological response of an outer-shelf, upper-slope sequence to rapid changes in Pleistocene eustatic sea level: Hole 820A, northeastern Australian margin., in: McKenzie, J.A., Davies, P.J., Palmer-Julson, A., et al. (Eds.), Proceedings of the Ocean Drilling Program, 133 Scientific Results, Proceedings of the Ocean Drilling Program. Ocean Drilling Program, College Station, TX, pp. 303-313. doi:10.2973/odp.proc.sr.133.1993 
Pillet, R., Pelletier, B., 2005. Tectonique active, tsunamis et sismicité en Nouvelle-Calédonie (No. 28), Notes techniques Sciences de la Terre. IRD-Nouméa, Nouméa.

Playton, T.E., Janson, X., Kerans, C., James, N.P., 2010. Carbonate slopes, in: Geological Association of Canada Facies Models. pp. 449-476.

Pratson, L.F., Coakley, B.J., 1996. A model for the headward erosion of submarine canyons induced by downslopeeroding sediment flows. Geol. Soc. Am. Bull. 108, 225-234. doi:10.1130/00167606(1996)108<0225:AMFTHE>2.3.CO;2

Principaud, M., Mulder, T., Gillet, H., Borgomano, J., 2015. Large-scale carbonate submarine mass-wasting along the northwestern slope of the Great Bahama Bank (Bahamas): Morphology, architecture, and mechanisms. Sediment. Geol. 317, 27-42. doi:10.1016/j.sedgeo.2014.10.008

Puga-Bernabéu, Á., Beaman, R.J., Webster, J.M., Thomas, A.L., Jacobsen, G., 2017. Gloria Knolls Slide: A prominent submarine landslide complex on the Great Barrier Reef margin of north-eastern Australia. Mar. Geol. 385, 68-83. doi:10.1016/j.margeo.2016.12.008

Puga-Bernabéu, Á., Webster, J.M., Beaman, R.J., Guilbaud, V., 2011. Morpholr a.' an. ${ }^{1}$ controls on the evolution of a mixed carbonate-siliciclastic submarine canyon system, Great Barrier Reef mare n, north-eastern Australia. Mar. Geol. 289, 100-116. doi:10.1016/j.margeo.2011.09.013

Puga-Bernabéu, Á., Webster, J.M., Beaman, R.J., Thran, A., López-Cabr sra, I tinestrosa, G., Daniell, J., 2020.

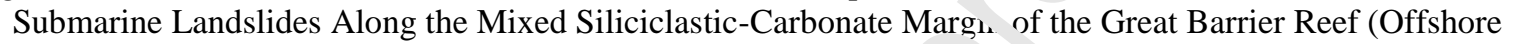
Australia), in: Submarine Landslides. American Geophysical Uni on (, GU), pp. 313-337. doi:10.1002/9781119500513.ch19

Puga-Bernabéu, Á., Webster, J.M., Braga, J.C., Clague, D.A., Г_..`on, A., Eggins, S., Fallon, S., Jacobsen, G., Paduan, J.B., Potts, D.C., 2016. Morphology and evolution of drow $r \mathrm{~d}$ c arbonate terraces during the last two interglacial cycles, off Hilo, NE Hawaii. Mar. Geol. 371, 57-81 dc : 10.1v16/j.margeo.2015.10.016

Rankey, E.C., Doolittle, D.F., 2012. Geomorpholog; of c rbonate platform-marginal uppermost slopes: Insights from a Holocene analogue, Little Bahama Bank, Bahama. Sedimentology 59, 2146-2171. doi:10.1111/j.13653091.2012.01338.x

Reijmer, J.J.G., Palmieri, P., Groen, R., 2012. C u. npo :tional variations in calciturbidites and calcidebrites in response to sea-level fluctuations (Exuma Sound, Bă.1z na s). Facies 58, 493-507. doi:10.1007/s10347-011-0291-z

Reijmer, J.J.G., Palmieri, P., Groen, R., Fl- queı, M., 2015. Calciturbidites and calcidebrites: Sea-level variations or tectonic processes? Sediment. Geol. Carı nnate slopes and gravity deposits 317, 53-70. doi:10.1016/j.sedgeo.2014.10.013

Reijmer, J.J.G., Swart, P.K., Bauch, ' O. ‘., Reuning, L., Roth, S., Zechel, S., 2009. A reevaluation of facies on Great Bahama Bank I: New facies say or Western Great Bahama Bank, in: Swart, P.K., Eberli, G.P., McKenzie, J.A. (Eds.), Perspectives in C, -bo 'ate Jeology: A Tribute to the Career of Robert Natman Ginsburg, Special Publications of the Internatı al Association of Sedimentologists. pp. 29-46.

Reolid, J., Betzler, C., Braga, J.c., Martín, J.M., Lindhorst, S., Reijmer, J.J.G., 2014. Reef slope geometries and facies distribution: controlling factors (Messinian, SE Spain). Facies 60, 737-753. doi:10.1007/s10347-014-0406-4

Richer de Forges, B., Chevillon, C., Laboute, P., Bargibant, G., Menou, J.-L., Tirard, P., 1988. La campagne CORAIL 2 sur le plateau des îles Chersterfield (N.O Coriolis et N.O Alis, 18 juillet au 6 août 1988) (No. 50), Rapports scientifiques et techniques. ORSTOM, Nouméa.

Richer de Forges, B., Laboute, P., Menou, J.-L., 1986. La campagne MUSORSTOM V aux iles Chesterfield, N.O Coriolis (5-24 octobre 1986) (No. 41), Rapports scientifiques et techniques. ORSTOM, Nouméa.

Richer de Forges, B., Pianet, R., 1984. Résultats préliminaires de la campagne CHALCAL à bord du N.O Coriolis (12-31 juillet 1984) (No. 32), Rapports scientifiques et techniques. ORSTOM, Nouméa.

Roger, J., Dudon, B., Krien, Y., Zahibo, N., 2014. Discussion About Tsunami Interaction with Fringing Coral Reef, in: Kontar, Y.A., Santiago-Fandiño, V., Takahashi, T. (Eds.), Tsunami Events and Lessons Learned, Advances in Natural and Technological Hazards Research. Springer Netherlands, Dordrecht, pp. 161-176. doi:10.1007/978-94007-7269-4_8 
Roger, J., Pelletier, B., Aucan, J., 2019. Update of the tsunami catalogue of New Caledonia using a decision table based on seismic data and marigraphic records. Nat. Hazards Earth Syst. Sci. 19, 1471-1483. doi:10.5194/nhess19-1471-2019

Rogers, K.G., Goodbred, S.L., 2010. Mass failures associated with the passage of a large tropical cyclone over the Swatch of No Ground submarine canyon (Bay of Bengal). Geology 38, 1051-1054. doi:10.1130/G31181.1

Rohling, E.J., Hibbert, F.D., Williams, F.H., Grant, K.M., Marino, G., Foster, G.L., Hennekam, R., de Lange, G.J., Roberts, A.P., Yu, J., Webster, J.M., Yokoyama, Y., 2017. Differences between the last two glacial maxima and implications for ice-sheet, $\delta 18 \mathrm{O}$, and sea-level reconstructions. Quat. Sci. Rev. 176, 1-28. doi:10.1016/j.quascirev.2017.09.009

Rouillard, P., Collot, J., Sutherland, R., Bache, F., Patriat, M., Etienne, S., Maurizot, P., 2017. Seismic stratigraphy and paleogeographic evolution of Fairway Basin, Northern Zealandia, Southwest Pacific: from Cretaceous Gondwana breakup to Cenozoic Tonga-Kermadec subduction. Basin Res. 29, 189-212. doi:10.1111/bre.12144

Rovere, A., Khanna, P., Bianchi, C.N., Droxler, A.W., Morri, C., Naar, D.F., 201 ? Submerged reef terraces in the Maldivian Archipelago (Indian Ocean). Geomorphology 317, 218-232. doi:10.1`'16/j.geomorph.2018.05.026

Sahal, A., Pelletier, B., Chatelier, J., Lavigne, F., Schindelé, F., 2010. A catalo 28 March 1875 to 30 September 2009. C. R. Geosci. 342, 434-447. doi ' ${ }^{2}$ v. $^{1}$ Vivij.crte.2010.01.013

Schlager, W., 1989. Drowning Unconformities on Carbonate Platforms, a: Anr cols on Carbonate Platforms and Basin Development, SEPM SPECIAL PUBLICATION.

Schlager, W., 1981. The paradox of drowned reefs and carbonate p1. form 3. Geol. Soc. Am. Bull. 92, 197-211. doi:10.1130/0016-7606(1981)92<197:TPODRA>2.0.CO;2

Schlager, W., Bourgeois, F., Mackenzie, G., Smit, J., 1988. B re r $^{1}$ es at Great Isaac and Site 626 and the History of the Florida Straits, in: Proceedings of the Ocean Drilling Pı or $n, 101$ Scientific Results, Proceedings of the Ocean Drilling Program. Ocean Drilling Program, ; 4 4_- -437. doi:10.2973/odp.proc.sr.101.1988

Schlager, W., Reijmer, J.J.G., Droxler, A., 1994. Hig. st nd shedding of carbonate platforms. J. Sediment. Res. 64, 270-281. doi:10.1306/D4267FAA-2B26-11D7-864d '0102C1865D

Schnyder, J.S.D., Eberli, G.P., Kirby, J.T., Shi, F., ^`hranirad, B., Mulder, T., Ducassou, E., Hebbeln, D., Wintersteller, P., 2016. Tsunamis caused b si « marine slope failures along western Great Bahama Bank. Sci. Rep. 6, 35925. doi: $10.1038 / \mathrm{srep} 35925$

Seton, M., Williams, S., Mortimer, N., Me. 're, S., Micklethwaite, S., 2016. Voyage report for SS2012V06 Eastern Coral Sea Tectonics (ECOSAT), R/: Soutıern Surveyor, October-November 2012. GNS Science report 2016, 51. doi:10.21420/G2TG6N

Skempton, A.W., Hutchinson, J.N I; 90 Stability of natural slopes and embankment foundations. State-of-the-art report, in: Proceedings of thr 7th nternational Conference on Soil Mechanics Foundation Engineering. Presented at the 7th International Co. fel_ _ en Soil Mechanics Foundation Engineering, Mexico City, Mexico, pp. 291335.

Smart, P.L., Palmer, R.J., Whitaker, F., Paul Wright, V., 1988. Neptunian Dikes and Fissure Fills: An Overview and Account of Some Modern Examples, in: James, N.P., Choquette, P.W. (Eds.), Paleokarst. Springer, New York, NY, pp. 149-162._doi:10.1007/978-1-4612-3748-8_8

Smith, W.H.F., Sandwell, D.T., 1997. Global Sea Floor Topography from Satellite Altimetry and Ship Depth Soundings. Science 277, 1956-1962. doi:10.1126/science.277.5334.1956

Spence, G.H., Tucker, M.E., 1997. Genesis of limestone megabreccias and their significance in carbonate sequence stratigraphic models: a review. Sediment. Geol. 112, 163-193. doi:10.1016/S0037-0738(97)00036-5

Taylor, F.W., Frohlich, C., Lecolle, J., Strecker, M., 1987. Analysis of partially emerged corals and reef terraces in the central Vanuatu Arc: Comparison of contemporary coseismic and nonseismic with quaternary vertical movements. J. Geophys. Res. 92, 4905. doi:10.1029/JB092iB06p04905

Tournadour, E., Mulder, T., Borgomano, J., Gillet, H., Chabaud, L., Ducassou, E., Hanquiez, V., Etienne, S., 2017. Submarine canyon morphologies and evolution in modern carbonate settings: The northern slope of Little Bahama Bank, Bahamas. Mar. Geol. 391, 76-97. doi:10.1016/j.margeo.2017.07.014 
Tournadour, E., Mulder, T., Borgomano, J., Hanquiez, V., Ducassou, E., Gillet, H., 2015. Origin and architecture of a Mass Transport Complex on the northwest slope of Little Bahama Bank (Bahamas): Relations between off-bank transport, bottom current sedimentation and submarine landslides. Sediment. Geol. 317, 9-26. doi:10.1016/j.sedgeo.2014.10.003

Tucker, M.E., Wright, V.P., 1990. Geological Background to Carbonate Sedimentation, in: Carbonate Sedimentology. Blackwell Publishing Ltd., Oxford, UK, pp. 28-69. doi:10.1002/9781444314175

Van de Beuque, S., Auzende, J.-M., Lafoy, Y., Missegue, F., 1998. Tectonique et volcanisme tertiaire sur la ride de Lord Howe (Sud-Ouest Pacifique). C. R. Acad. Sci. 326, 663-669. doi:10.1016/S1251-8050(98)80258-9

Vially, R., Lafoy, Y., Auzende, J.-M., France, R., 2003. Petroleum Potential of New Caledonia and its offshore basins. Presented at the AAPG International Conference, Barcelona, Spain, Barcelona, Spain.

Waelbroeck, C., Labeyrie, L., Michel, E., Duplessy, J.C., McManus, J.F., Lambeck, K., Balbon, E., Labracherie, M., 2002. Sea-level and deep water temperature changes derived from benthic foraminifera isotopic records. Quat. Sci. Rev., EPILOG 21, 295-305. doi:10.1016/S0277-3791(01)00101-9

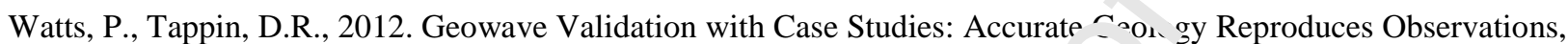
in: Yamada, Y., Kawamura, K., Ikehara, K., Ogawa, Y., Urgeles, R., Mosh r, D. Chaytor, J., Strasser, M. (Eds.), Submarine Mass Movements and Their Consequences. Springer Nether' „ـ. 's, _urdrecht, pp. 517-524. doi:10.1007/978-94-007-2162-3_46

Webster, J.M., Beaman, R.J., Puga-Bernabéu, Á., Ludman, D., Renema. 'T , Wust, R.A.J., George, N.P.J., Reimer, P.J., Jacobsen, G.E., Moss, P., 2012. Late Pleistocene history of $t$ irbic te sedimentation in a submarine canyon off the northern Great Barrier Reef, Australia. Palaeogeogr. Palaeoclı. ${ }^{n+}{ }^{\prime \prime} 1$. Palaeoecol. 331-332, 75-89. doi:10.1016/j.palaeo.2012.02.034

Webster, J.M., Davies, P.J., 2003. Coral variation in two deep t 11 ores: significance for the Pleistocene development of the Great Barrier Reef. Sediment. Geol. Late Luaternary Reef Development 159, 61-80. doi:10.1016/S0037-0738(03)00095-2

Webster, J.M., Braga, J.C., Humblet, M., Potts, D.C., L. 'ı, Y., Yokoyama, Y., Fujita, K., Bourillot, R., Esat, T.M., Fallon, S., Thompson, W.G., Thomas, A.L., ' ' 'n, H., MicGregor, H.V., Hinestrosa, G., Obrochta, S.P., Lougheed, B.C., 2018. Response of the Great Barrier Reef $\iota$ sea-level and environmental changes over the past 30,000 years. Nature Geoscience 11, 426-432._doi:10.10 8/, , ' 561-018-0127-3

Webster, J.M., George, N.P.J., Beaman, R.`., ' 'ilı, J., Puga-Bernabéu, Á., Hinestrosa, G., Abbey, E.A., Daniell, J.J., 2016. Submarine landslides on the Grea. Barrier Reef shelf edge and upper slope: A mechanism for generating tsunamis on the north-east Australial 'oast? Mar. Geol. 371, 120-129. doi:10.1016/j.margeo.2015.11.008

Wei, G., Kirby, J.T., 1995. Time-D^nena nt Numerical Code for Extended Boussinesq Equations. J. Waterw. Port Coast. Ocean Eng. 121, 251-2๔1. ¿ : 10.1061/(ASCE)0733-950X(1995)121:5(251)

Wei, G., Kirby, J.T., Grilli, , T., Sub amanya, R., 1995. A fully nonlinear Boussinesq model for surface waves. Part 1. Highly nonlinear unsteady 'vaves. J. Fluid Mech. 294, 71-92. doi:10.1017/S0022112095002813

Williams, S., Mortimer, N., Etıuıne, S., Whittaker, J., Herold, J., O’Toole, L., Sauermilch, I., Tobin, J., Yeung, S., Seton, M., Collot, J., 2016. Voyage report for IN2016T01 Eastern Coral Sea Tectonics followup (ECOSAT II), R/V Investigator, June-July 2016. GNS Science report 2016, 56. doi:10.21420/G2KW23

Wilson, P.A., Roberts, H.H., 1995. Density cascading; off-shelf sediment transport, evidence and implications, Bahama Banks. J. Sediment. Res. 65, 45-56. doi:10.1306/D426801D-2B26-11D7-8648000102C1865D

Woodroffe, C.D., Webster, J.M., 2014. Coral reefs and sea-level change. Mar. Geol. 352, 248-267. doi:10.1016/j.margeo.2013.12.006

Wright, V.P., Burchette, T.P., 1996. Shallow-Water Carbonate Environments, in: Reading, H.G. (Ed.), Sedimentary Environments: Processes, Facies and Stratigraphy. Oxford, pp. 325-394.

Wunsch, M., Betzler, C., Eberli, G.P., Lindhorst, S., Lüdmann, T., Reijmer, J.J.G., 2018. Sedimentary dynamics and high-frequency sequence stratigraphy of the southwestern slope of Great Bahama Bank. Sediment. Geol. 363, 96117. doi:10.1016/j.sedgeo.2017.10.013

Wunsch, M., Betzler, C., Lindhorst, S., Lüdmann, T., Eberli, G.P., 2017. Sedimentary dynamics along carbonate slopes (Bahamas archipelago). Sedimentology 64, 631-657. doi:10.1111/sed.12317 
Yamano, H., Abe, O., Matsumoto, E., Kayanne, H., Yonekura, N., Blanchon, P., 2003. Influence of wave energy on Holocene coral reef development: an example from Ishigaki Island, Ryukyu Islands, Japan. Sediment. Geol., Late Quaternary Reef Development 159, 27-41. doi:10.1016/S0037-0738(03)00093-9

Yokoyama, Y., Esat, T.M., Thompson, W.G., Thomas, A.L., Webster, J.M., Miyairi, Y., Sawada, C., Aze, T., Matsuzaki, H., Okuno, J., Fallon, S., Braga, J.-C., Humblet, M., Iryu, Y., Potts, D.C., Fujita, K., Suzuki, A., Kan, H., 2018. Rapid glaciation and a two-step sea level plunge into the Last Glacial Maximum. Nature 559, $603-607$. doi:10.1038/s41586-018-0335-4

Yokoyama, Y., Lambeck, K., De Deckker, P., Johnston, P., Fifield, L.K., 2000. Timing of the Last Glacial Maximum from observed sea-level minima. Nature 406, 713-716. doi:10.1038/35021035 
The authors declare no conflict of interest. 


\section{Highlights}

- The Lansdowne Bank is a partly drowned, isolated carbonate platform of the SW Pacific.

- Morphologies of the bank top and adjacent slopes have been investigated.

- Spectacular bank margin collapses and slope failures are described.

- Margin collapses can affect the entire external reef rim and influence subsequent reef growth.

- Numerical modeling of the tsunamigenic potential of these slides has been performed. 


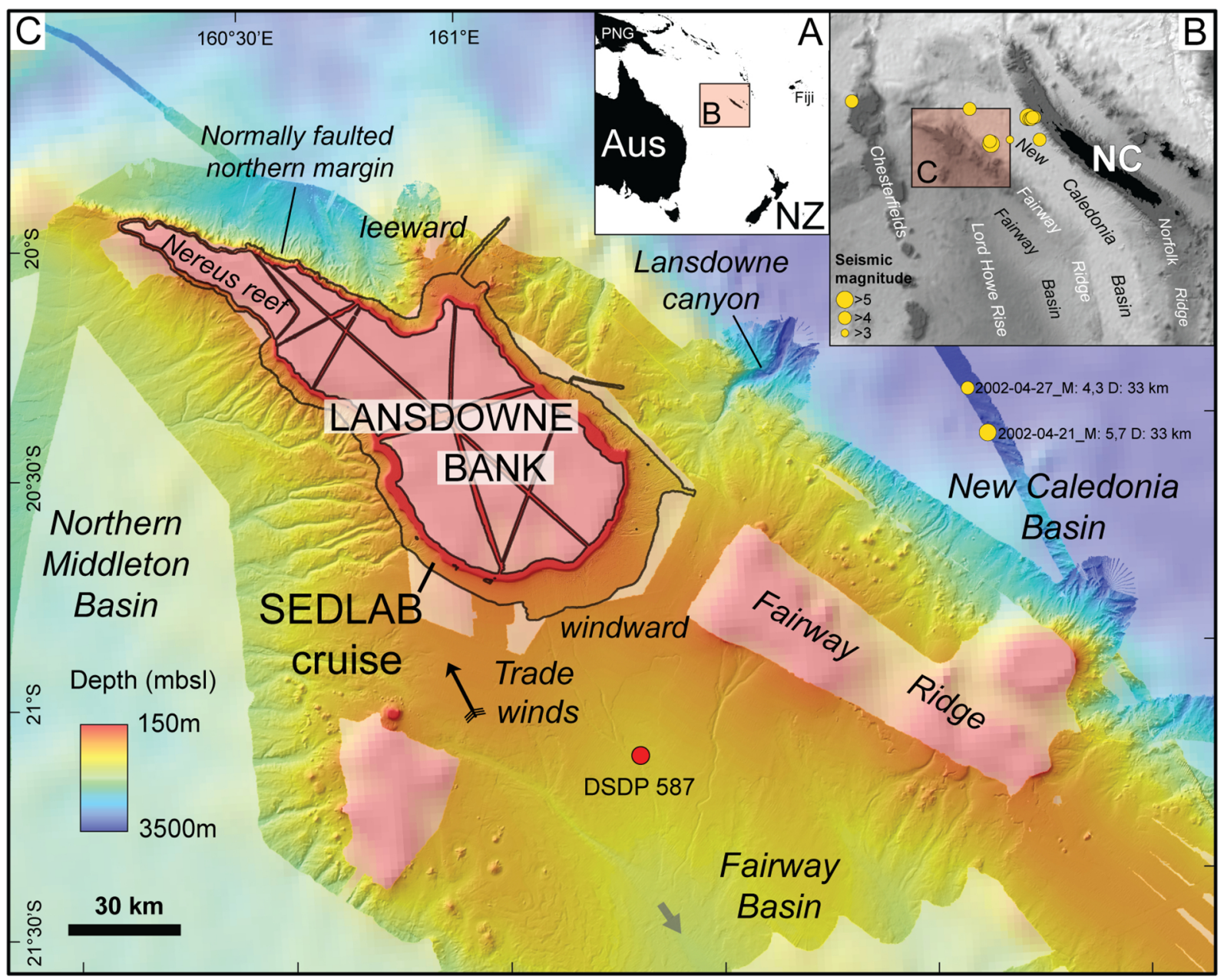

Figure 1 


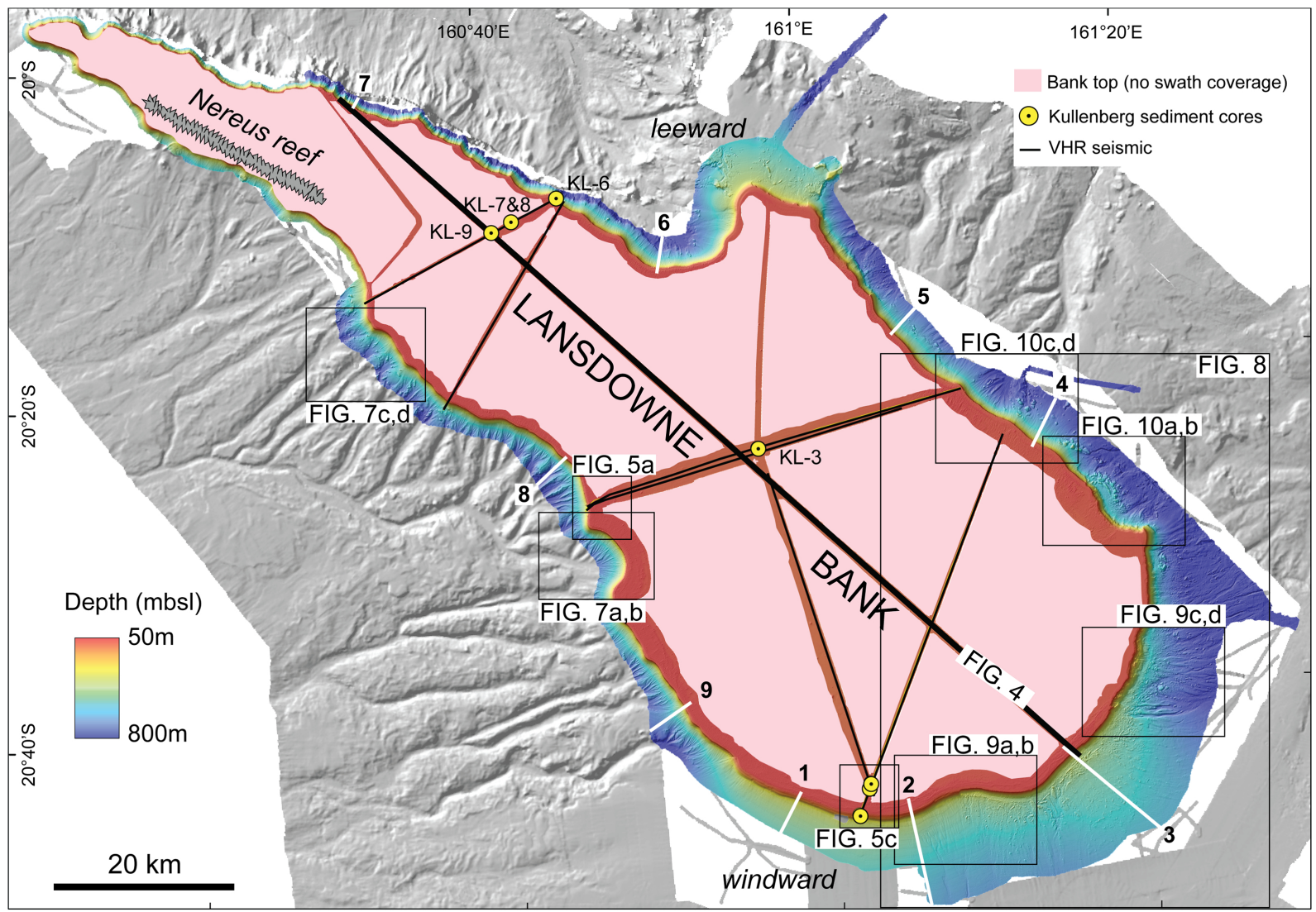

Figure 2 


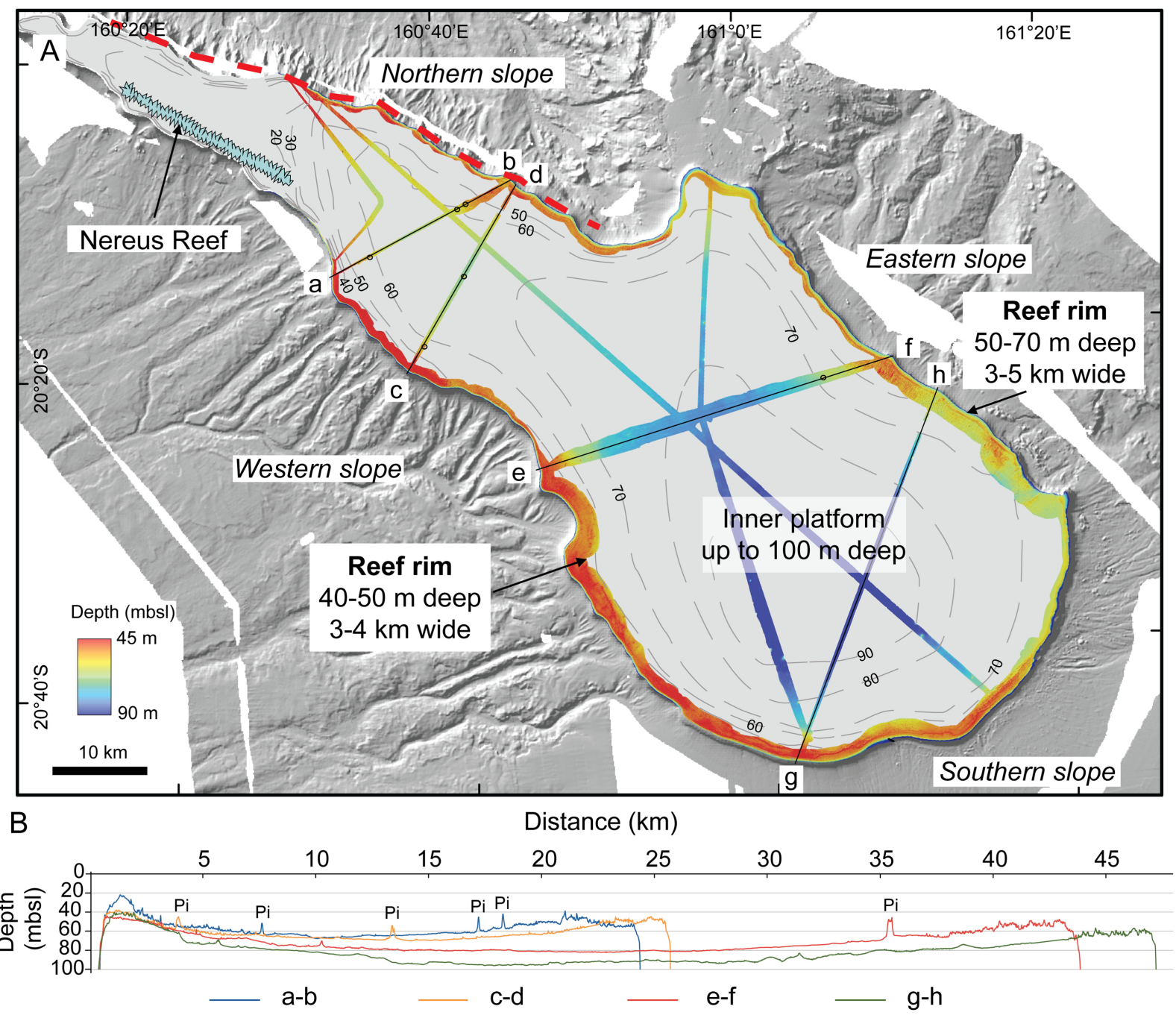

Figure 3 


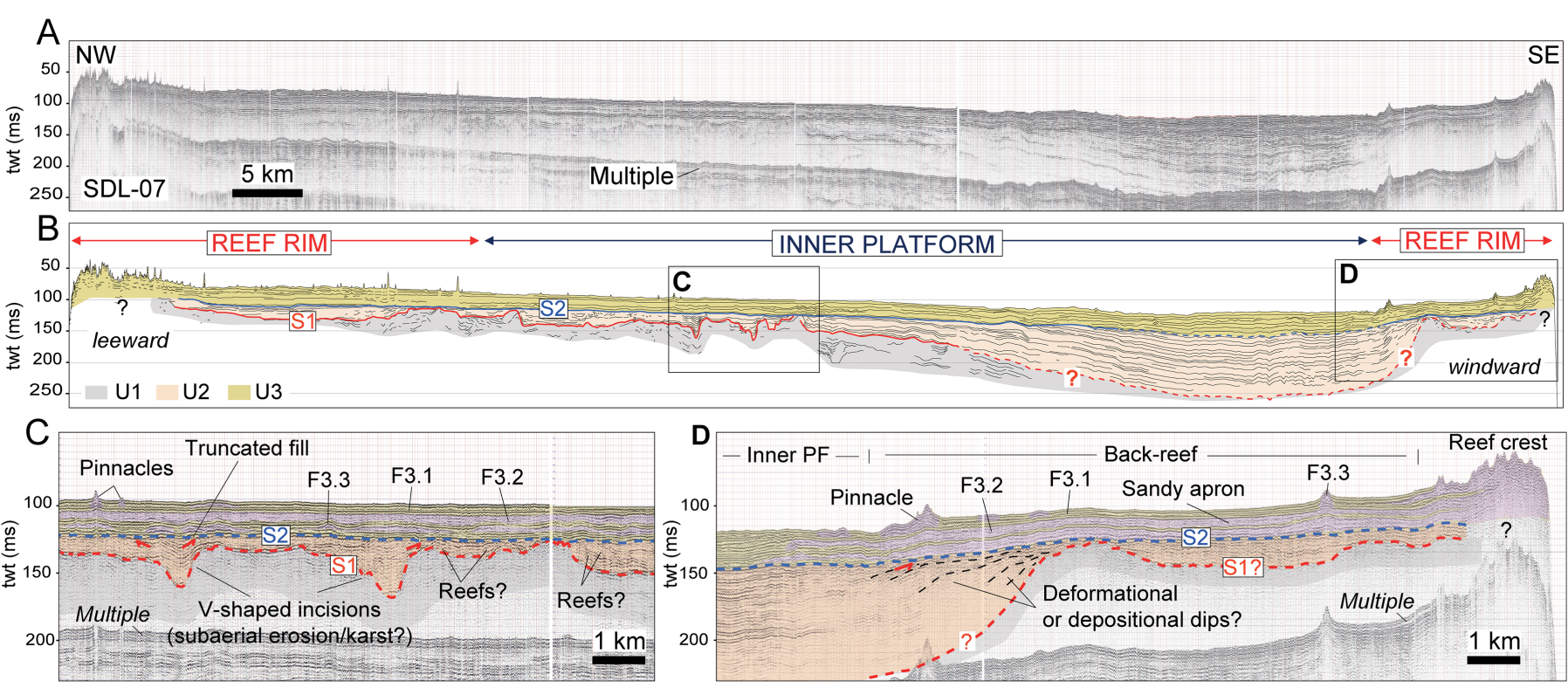

Figure 4 

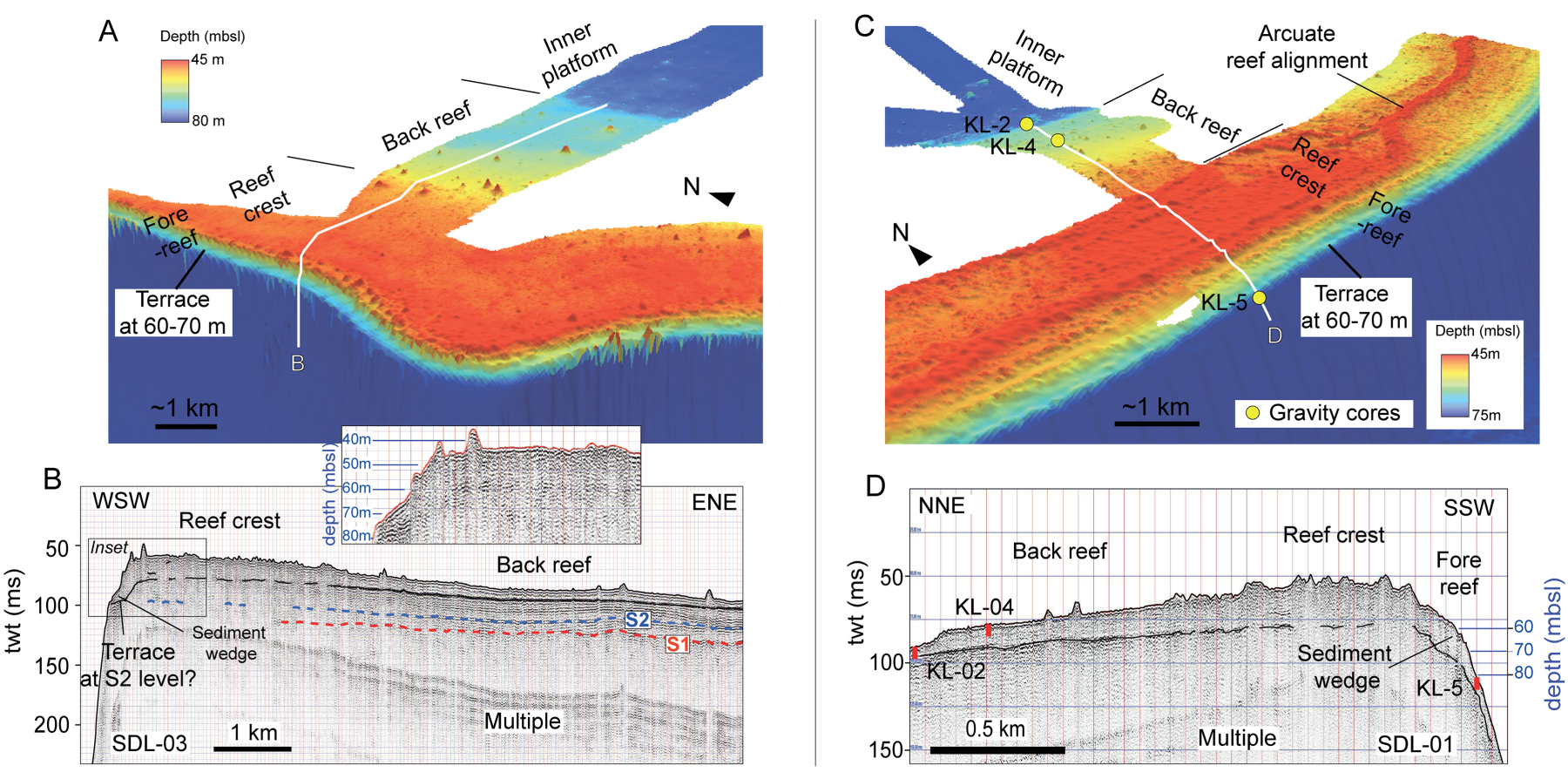

Figure 5 


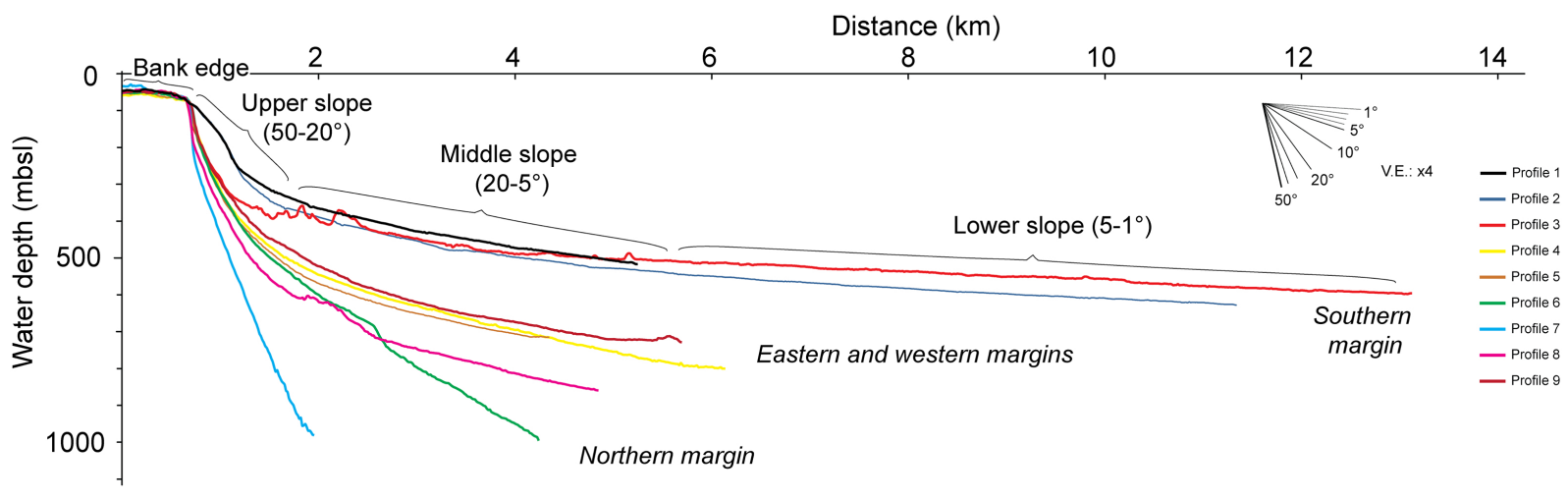

Figure 6 


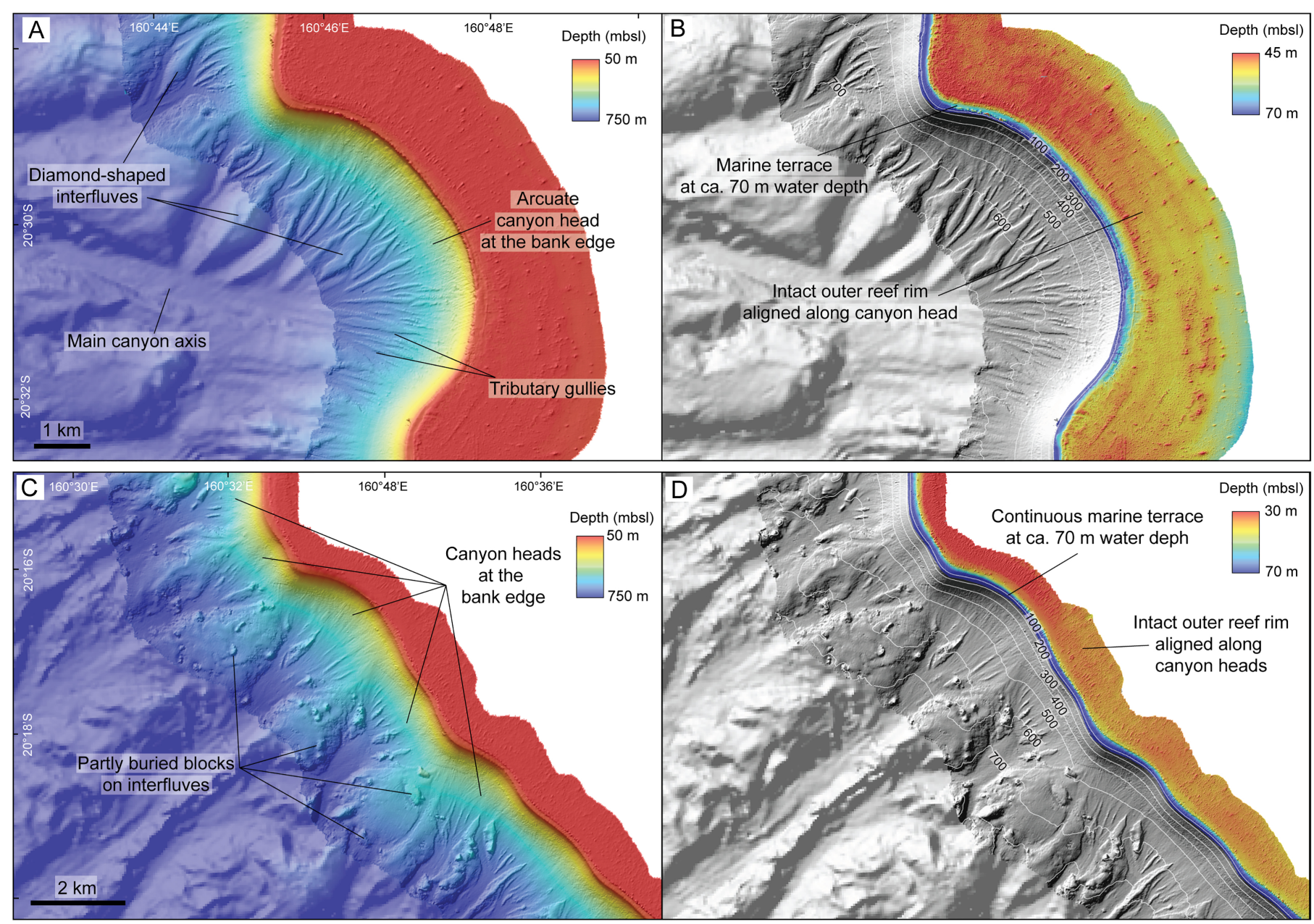

Figure 7 


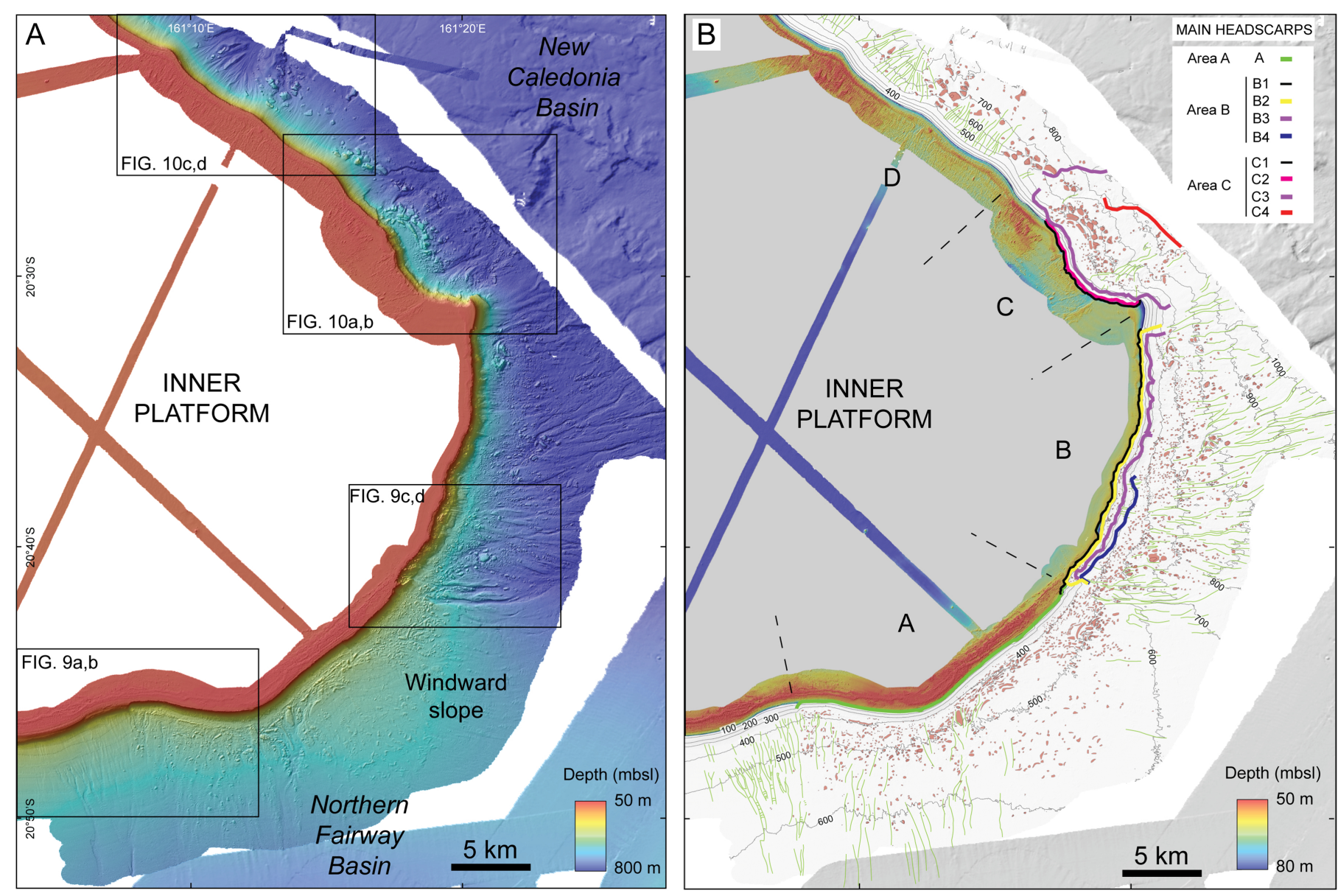

Figure 8 


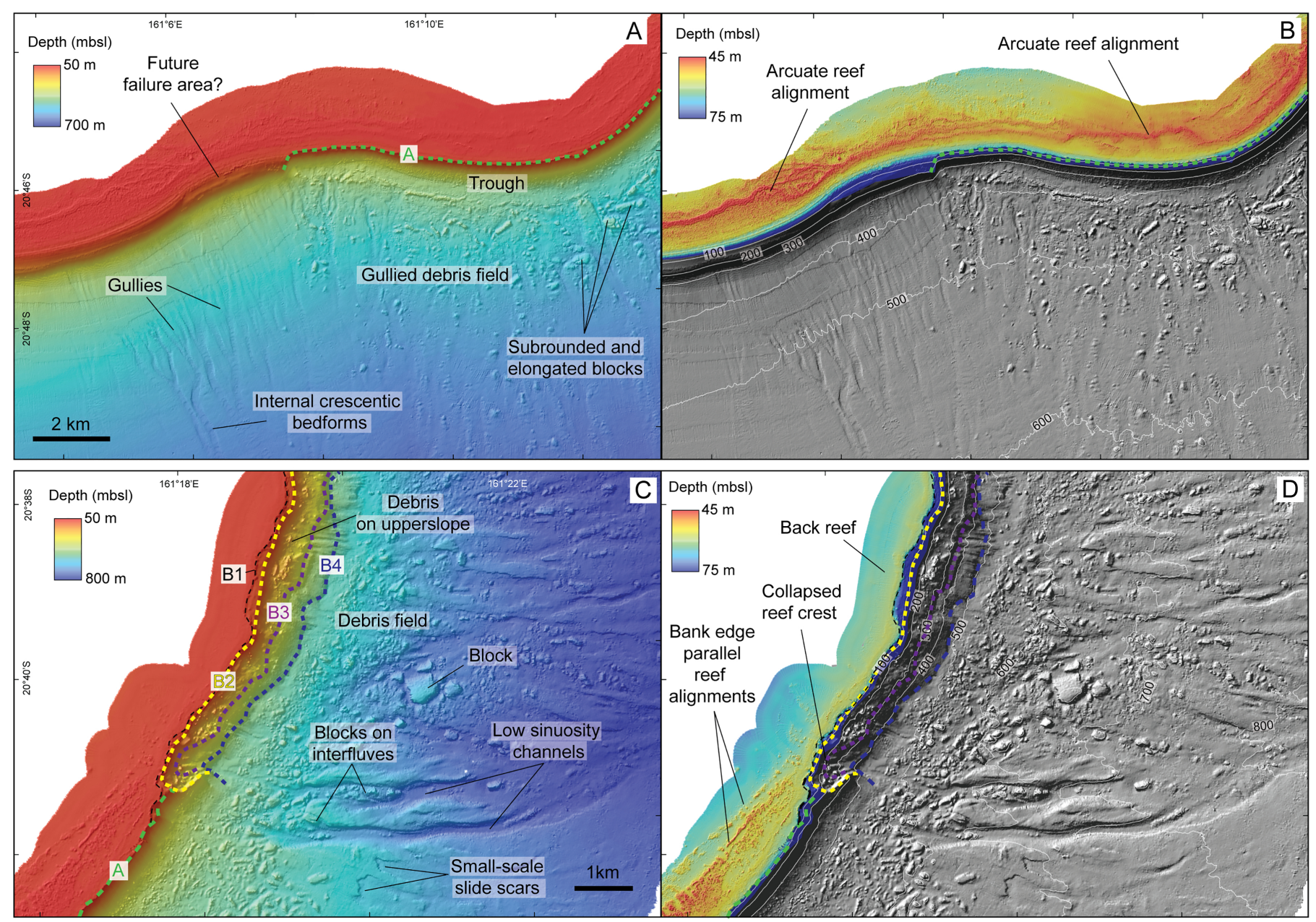

Figure 9 


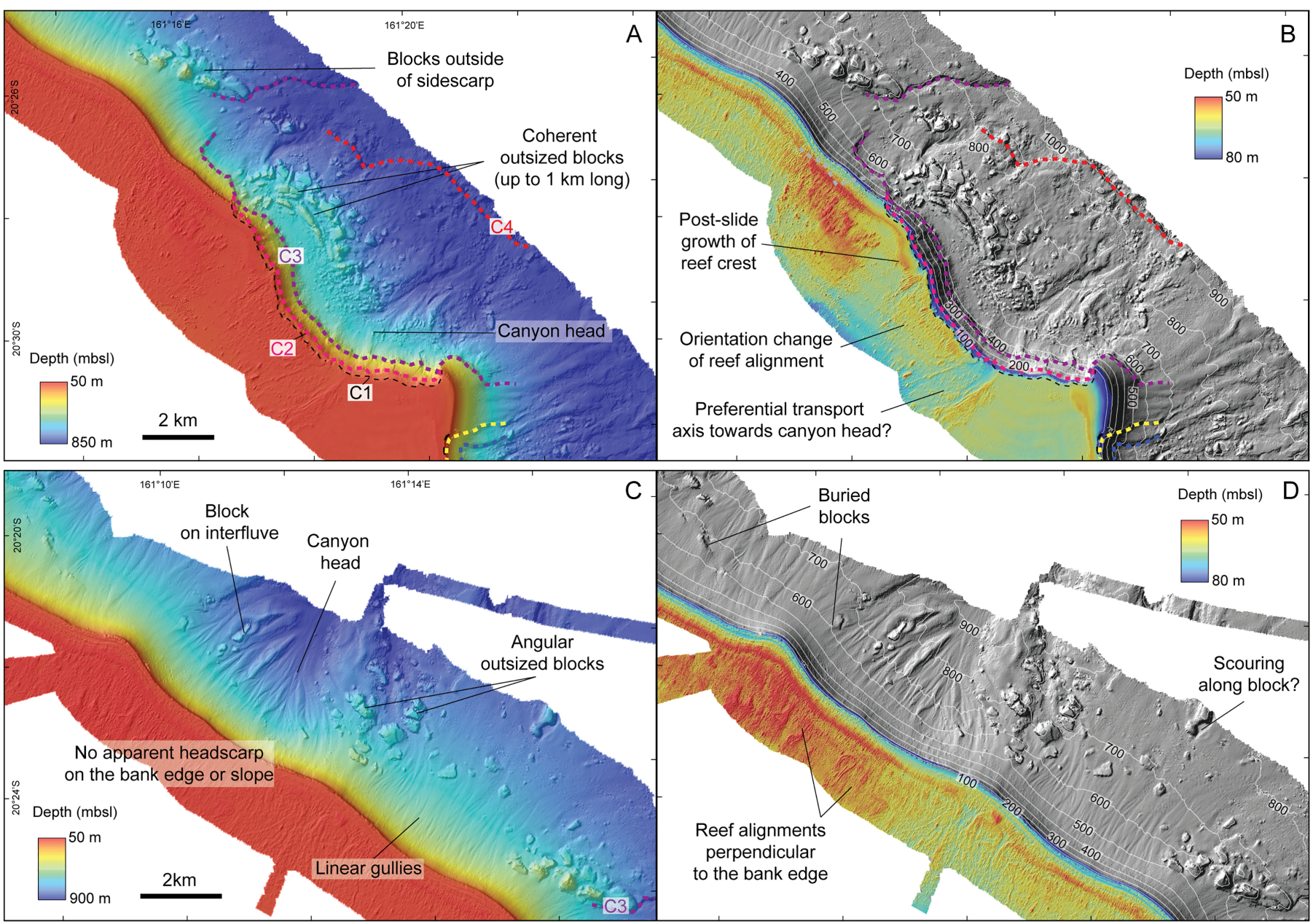

Figure 10 


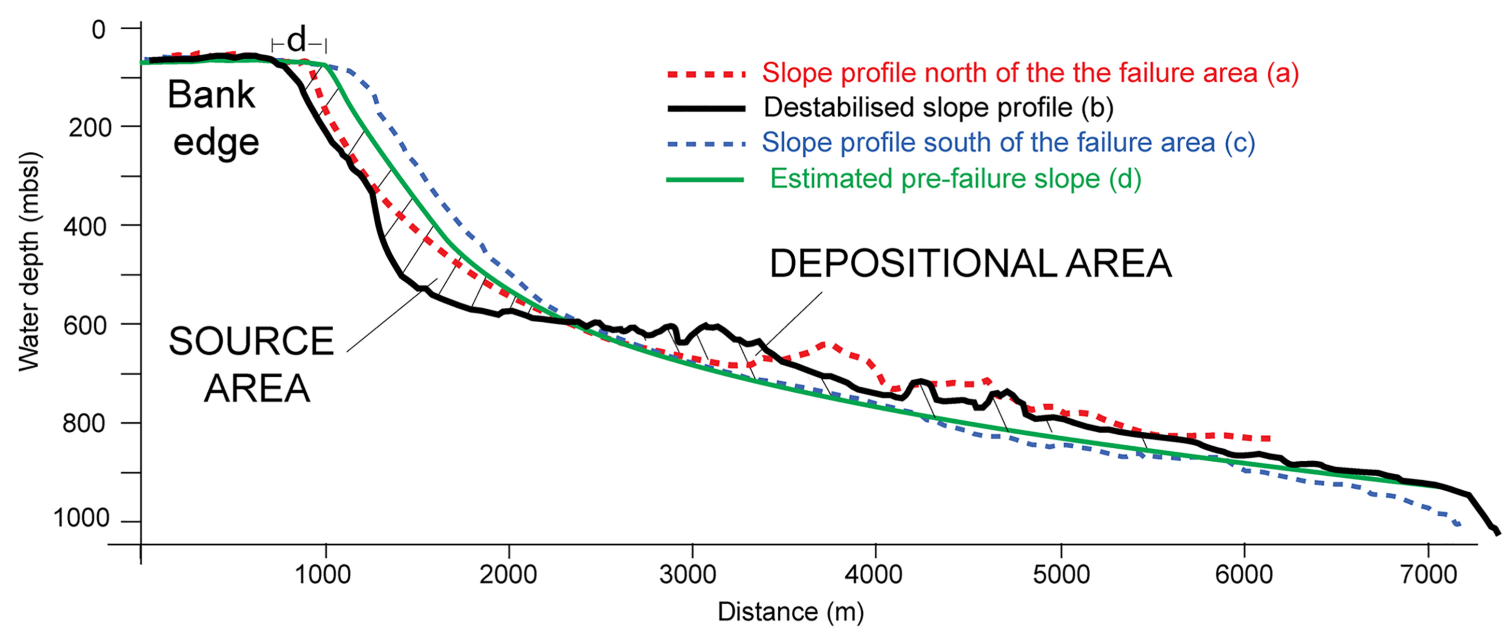

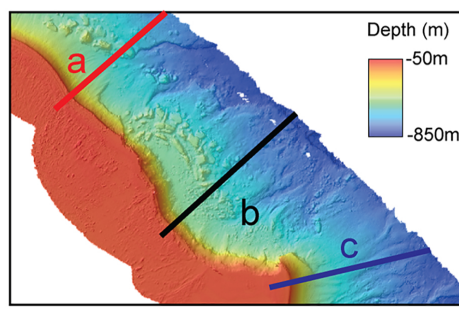

Present day bathymetry

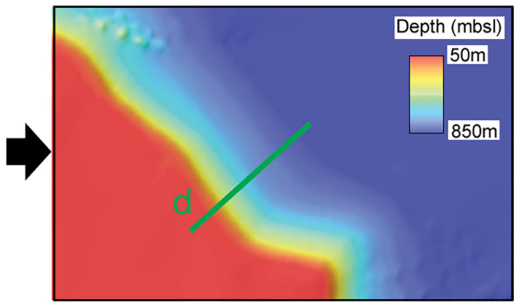

Estimated pre-slide bathymetry

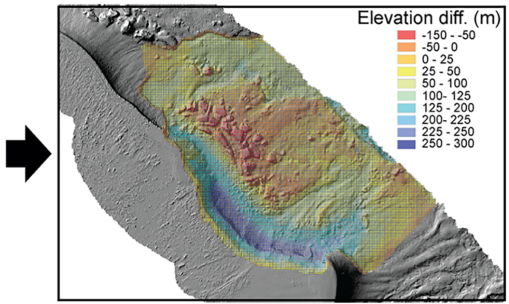

Elevation difference map showing erosion and accumulation areas 


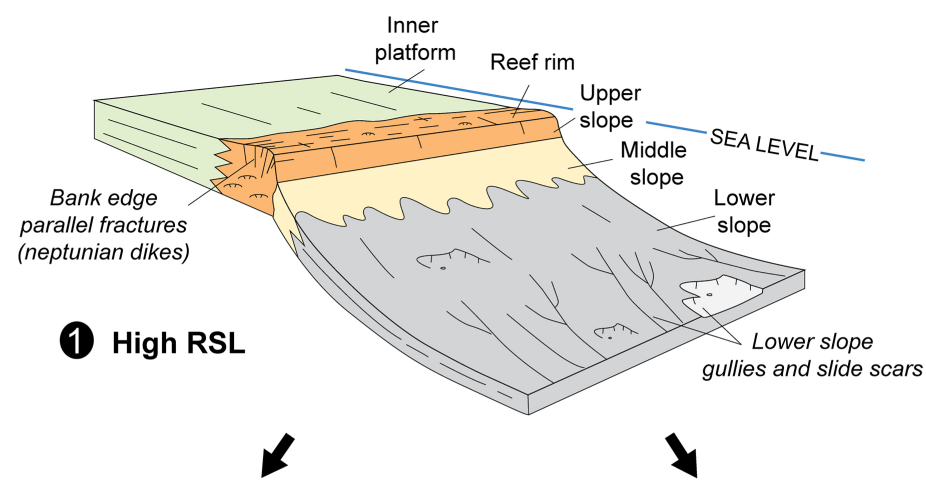

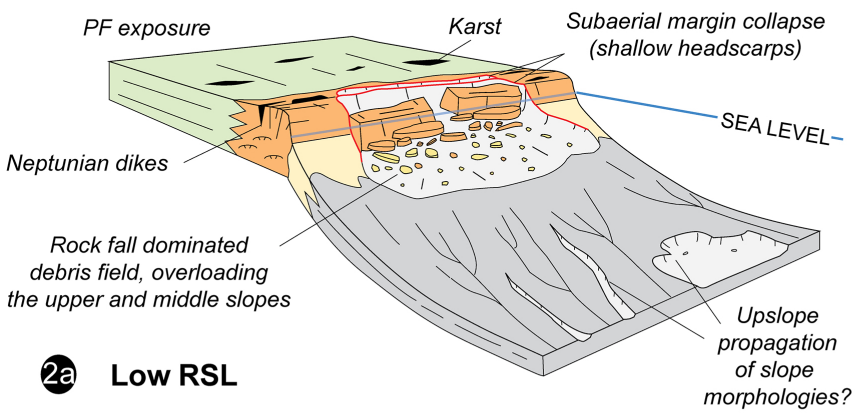

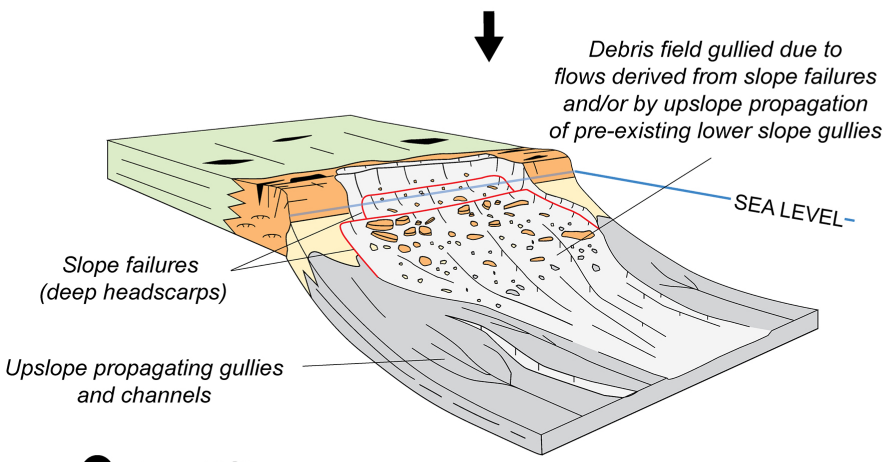

(3a) Low RSL
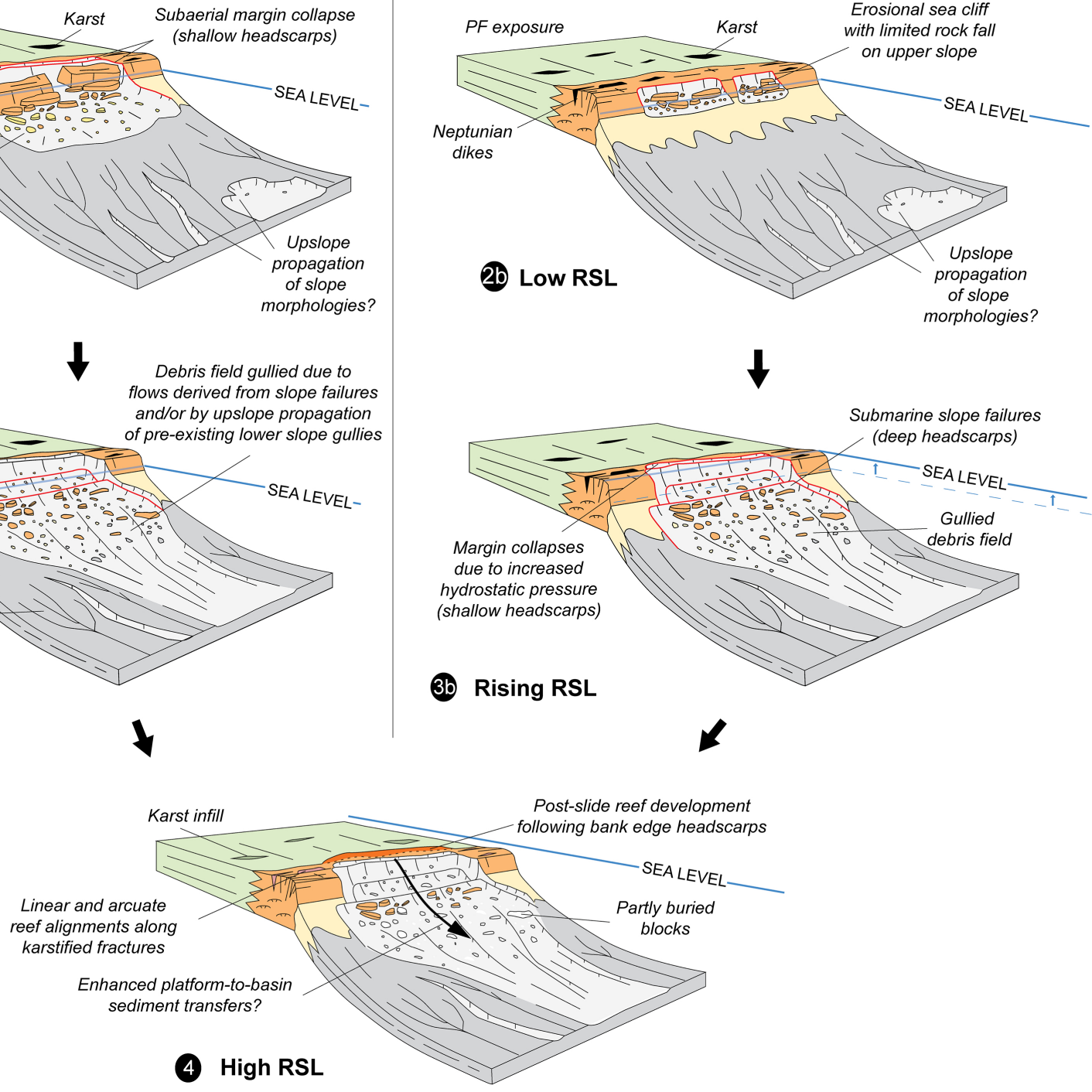

Figure 12 


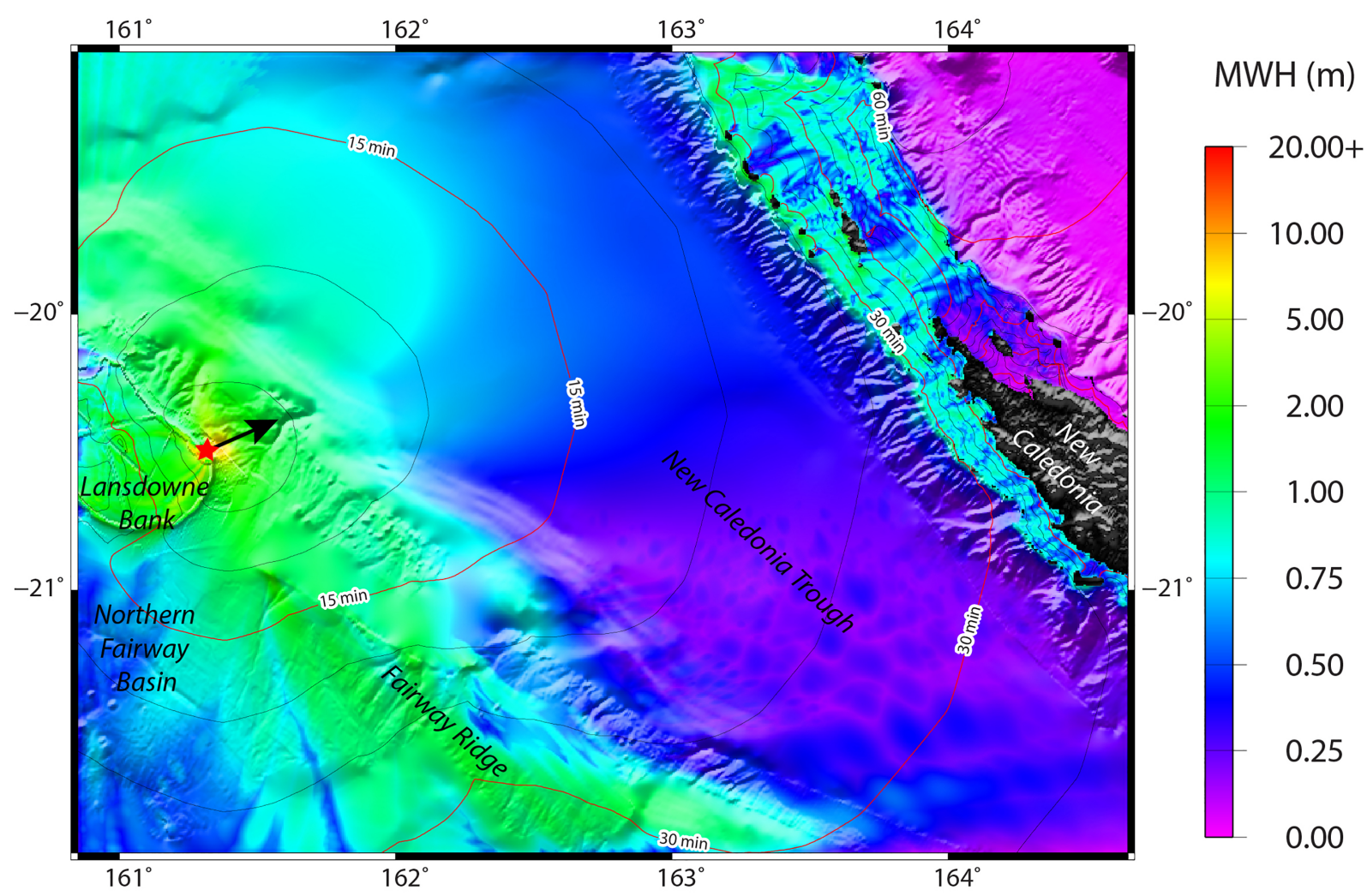

Figure 13 